SYSTEM DESCRIPTION NO. 8

DECAY HEAT REMOVAL SYSTEM

ISSUE

1

2

3
DATE

Soptember 14, 1955

June 29, 1956

December 6, 1956

$\infty$ 1. 


\section{DISCLAIMER}

This report was prepared as an account of work sponsored by an agency of the United States Government. Neither the United States Government nor any agency Thereof, nor any of their employees, makes any warranty, express or implied, or assumes any legal liability or responsibility for the accuracy, completeness, or usefulness of any information, apparatus, product, or process disclosed, or represents that its use would not infringe privately owned rights. Reference herein to any specific commercial product, process, or service by trade name, trademark, manufacturer, or otherwise does not necessarily constitute or imply its endorsement, recommendation, or favoring by the United States Government or any agency thereof. The views and opinions of authors expressed herein do not necessarily state or reflect those of the United States Government or any agency thereof. 


\section{DISCLAIMER}

Portions of this document may be illegible in electronic image products. Images are produced from the best available original document. 
8:I INTRODUCTION。

8.1.1 System Functions 0000000000000000000000000000000000000 B 1

8.1.2. Summary Description of Systom.0000000000000000000000000000801

8.1.3 System Design Requirement8.0000000000000000000000.000000000000008.2

8.2 DETAILED DESCRIPTION OF SYSTEM 000000000000000000000000000000000083

8.2:1 Mechanical Components and Piping 000000000000000000000000000000803

8.2.2 Instruments 00000000000000000000000000000000000000000000008 8 d

8.2 .3 Control8.0.000.00000000000000000000000000000000000000000000008.5

8.3 PRINCIPLES OF SYSTEM OPERATION $00000000000000000000000000000000000008-5$

8.3.1 Starting 0000000000000000000000000000000000000000000000008.5

8.3.2 Running 0000000000000000000000000000000000000000000000000000000866

8.3.3 Stopping00.0000000.0000000000000000000000000000000000000000000008007

8.3 .4 Special or Infrequento $0.00000000000000000000000000000000000008=8$

8.3.5 Emergency 0000000000.0000000000000000000000000000000000000000000809

8.4 SAFETY PRECAUTIONS 00000000000000000000000000000000000000000000009

8.4.1 Hazards.00000000000000000000000000000000000000000000000000000008009

8.4 .2 Precautions 0000000000000000000000000000000000000000000000009

8.5 PREVENTATIVE MAINTENANCE 00000000000000000000000000000000000000000010

APPENDIX A 00000000000000000000000000000000000000000000000000000000000011

APPENDIX B

APPENDIX C00000000000000000000000000000000000000000000000000000000000008-13 
DECAY HEAT REMOVAL SYSTEM

8.I Introduction

8.1.1 STSTEM FUNCTIONS

8.1.1.1 The primary function of the PWR Decay Heat Romoral Systam is to dissipate, at a rate sufficient to protect the core from damige the reactor decay heat following an emergency shutodown due to the loss of electrical power to the reactos coollant pumps. As a consequence of . performing this basic function, the system will onsire tho intogrity of the plant during such an emergency:

8.1.1.2 As an adjunct to this primary requirement, the Deeay Heat Removal system may be used for the removal of reactor heat during plant shut-downs or: during plant operation at low reactor powero 100el. Although the major function of the system is, of necessity, performed without the assistance of any electrical power, the auxiliaxy function, $r$ : may be accomplished with plant power available.

\subsubsection{SUMMARY DESCRIPTION OF SYSTEM}

8.1.2.1 The system consists, primarily, of a steam relief raire sot to operate at 707 psia and sized to dissipats $7000 \mathrm{kw}$ of heato This relief valve is installed in the turbine room basement on the $12^{\text {th }}$ stears line from the No: 2 reactor coolant loop steam generator. The relios valve is normally isolatied from the steam header by a motorooperated gate valve. However, the isolation valve opens automatically upon failure of the a-c power supply to all of the reactor coolant pumps? During relief valve operation, reactior coolant is induced to flow by natural conroction through the primary 100ps. In this manner decay heat is removed from the reactor, transfersed across the stoum generse

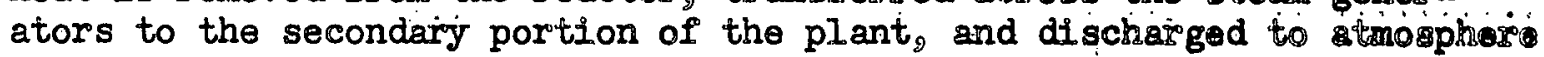
through the decay heat steam relief valve. The calculations from when the magnitude of natural convection cooliant flow-rote was estamated aro contained in Appendix $C_{2}{ }^{88}$ Supporting Calculationg"8. Also Included in that appendix are the calculations used in determining the size of the relief ralve and its setting.

8.1.2.2 To accomplish the auxiliary functions mentioned in paragxaph 8.1 .1 .2 , the isolation valre for the steam relief valvo is remotely operable from the Main Control Room. 
8.1.2.3 Since reactor decay heat is dissipated by discharging steam from the secondary portion of the plant to the atmosphere, make up water will, in time, be required for the steam generators. During an emergency involving the loss of all electrical power to the reactor coolant pumps it must be assumed that power is also lost to the boiler feedwater pumps. In order to enable make aup, then, a charging pump mast bo used, since it may draw its power from the emergency diesel generator. Water is directed from the Coolant Charging System fill header thru a cross-over line to the boiler feedwater pumps' discharge header. A relief valve is installed on this line to prevent inadvertant overpressuring of the boiler feedwater piping. To permit maintanse of the relief valve a stop valve is installed in the crossoover line on the feedwater side of the relief valve. Calculations supporting the adequacy of the secondary water volume in the steam generators until make-up can begin are included in Appendix $C_{\text {。 }}$

8.1.2.4 The major system capabilities, limitations and other constants established during the design of the Decay Heat Removal System are listed in tabular form in Appendix $\overline{\mathrm{B}}_{2}$ "System Design Data Summary"

\subsubsection{SYSTEM DESIGN REQUIREMENTS}

8.1.3.1 Reactor decay heat removal requirements are based on a plant electrical output of $100 \mathrm{MW}$ for 600 hours before the emergency occurs.

8.1.3.2 The reactor plant must be capable of sustaining, without damage, casualties interrupting normal heat removal schemes, including a como plete loss of a-c electrical power, for:

(a) Any time up to two hours without requiring action by plant operating personnel.

(b) Any time up to eight hours with corrective action by operating personnel using only station facillties.

(c) Indefinitely, with corrective action within elght hourg by operating personnel and availability of external to-station power or facilities.

8.1.3.3 Corrective action by plant operating personnel must not require entrance into the plant container.

8.1.3.4 Regardless of the type of casualty and independent of the availability of personnel, the reactor will not release fission products external to the primary systems as long as the primary plant integrity has not been violated. 
8.1.3.5 The system is to be capable of auxiliary functions such as the removal of decay heat after plant shut-down or during oparation at low power levels.

8.1.3.6 The system design is to be based on the PWR reactor coolant pump flow coastdown curve and on the Mark I STR decay heat curves shown in Appendix C.

\subsection{Detailed Description of System}

\subsubsection{MECHANICAL COMPONENTS AND PIPING}

\subsubsection{Steam Relief Valve}

8.2.1.1.1 GENERAL DESCRIPTION o The steam relief valve, itom 11- HI 5-1 shown on Fig. 8-1, serves as the heat sink thru which reactor decay heat is dissipated to the outdoors. The valve is installed on the steam line from the No. 2 steam generator in the Turbine Room Base ment and is separated from the steam Iine by motoseoperated isolation valve $11-H 1.2-1$.

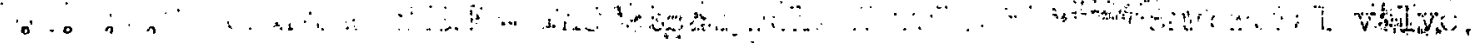

8.2.1.1.2 CONSTRUCTION क The steam relief valve is a commercial valve of the spring loaded, safety relief typo. The body material is carbon steel while the trim materials are primarily type 325istainless stoel. The valve has a 2 inch inlet connection and a 3oinch outlet connection. The set pressure of the valve is 707 psia and its capácity is 33,600 1.6 per hour at $6 \%$ accumulation. The valve has approximately $4 \%$ blowdown。

\subsubsection{Motor Operated Gate Valve}

8.2.1.2.1 GENERAL DESCRIPTION - The motor operated gato valve, Itom $1 l_{\omega H}{ }_{2} l_{2}$ is used to isolate the steam relief valve from the steam Iine during normal plant operation. This feature is required by the fact that the setting of the decay heat steam relief valve is less than the boiler pressure will be under certain normal low load conditions. Als $\theta_{2}$ the setting of the decay heat stean relief valve is lower than that of any of the Main Steam System relief valves.

8.2.1.2.2 CONSTRUCTION - The valve is a commercial, carbon steel, wedge gate valve equipped with a doc motor operator. "The valve has 2 inch connections and a primary service pressure rating of 600 Ib ASA Class A. The electrical circuitry for the motor operater, which draws its power from the station batteries, is such that loss of all oloctio rical power to the reactor coolant pumps will cause the motor oporator to be energized to open the gate valve. 


\subsubsection{Water Relief Valve}

8.2.1.3.1 GENERAL DESCRIPTION क The water relief valve, itom II $\mathrm{mH} 5 \mathrm{~m} 2$ is installed in the Turbine Room Basement on the crossover line between the Coolant Charging System and the Boiler Feedwater System. The valvo is required to protect the boiler food piping, which is rated at. 1200 psig, when a charging pump, which can develop a discharge pressure of 3000 psig, is being used, during an omergency, to supply water to the steam drums via the crossover line and the boiler feed piping.

$8.2 .1 .3 .2^{\circ}$ CONSTRUCTION - The water relief vaive is a comercial valve of the spring-loaded, safety rellef typo. It has a $3 / 4$ irich inlet con nection and a loinch outlet connection and has a body rating of 2000 psig at 4000F. The valve is set to operate at 1200 pisig and has a capacity of $50 \mathrm{gpm}$ at $10 \%$ accumulation. Thie valve has approximately $5 \%$ blowdown. The set pressure of the valve is approximately 150 psi above the maximum head which can be developed by the boller foed pumps oo that in normal operation the relief valve will not be actuated by the bollor feod pump pressure.

\subsubsection{Crossover Iine Isolation Valve}

8.2.1.4.1 GENERAI DESCRIPTION - The crossover IIno isolation Falve: item $11-H 16-1$, is installed in the crossover line neare the junction of that line and the boiler feed pump discharge header, in the Turbine liow Basement. The valve is norimally open but will be closed to permit matio tenance of the crossover Iine or of the water rellef valve.

8.2.1.4.2: CONSTRUCTION - The cros8over Iine 18oletion valve is a 3inch commercial, carbon steel gate valve: The primary sorvice rating of the valve is 600 Ib ASA Class A.

\subsubsection{Piping}

8.2.1.5.I The only run of pipe in the Dood Heat Removal Systam is the crossover line between the Coolant Charging Systen and the Boller Foed. water System: That line is 3-inch, schedule $\mathrm{BO}_{2}$ carbon steol pipo. The iine begins in Auxiliary Equipment Room No: I just dormstream of vilvo 08-11.6-39 in the Coolant Charging system fill header and ends it the boller feed pump discharge header in the Turbine Room Basement.

\subsubsection{INBTROMENTS}

8.2.2.1 The Decay Heat Removal System has no instrumentation strictly for its own use, but the operation of the systow sany be followed by the use of the instrumentation of the Reactor Coolant, Main Stram, and Boiler Feod. 
water Systems. Detailed descriptions of that instrumentation can be found in the respective system descriptions in Volume II of the Shippingport Atomic Power Station Manual.

\section{2 .3 CONTROLS}

\subsubsection{Motor Operated Gate Valve Control}

8.2.3.1.1 The control switch for motor operated gate valve, 1.1.HI.2.I, is located on the Turbine Section of the Main Control Console in the Main Control Room。 It is a three oposition selector switch labelled "Decay Heat Selector Switch and is equipped wi.th 2 red and a green indicating light. The switch has three positions: "OPEN" "BATO", and "CLOSE"。 The red indicating light is illuminated when the valve is open and the green light is illuminated when the valve is closed. Duroing normal. plant operation the selector switch is kept in the "AUTO" position to

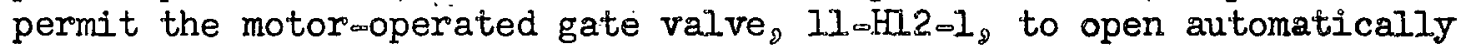
should electrical power to the reactor coolant pumps be lost. The "rOPEN" and "CLOSE" positions are used during plant shutdown or Low power operation

\subsection{Principles of System Operation}

\subsubsection{STARTING}

8.3.1.1 The Decay Heat Removal System is placed into operation either automatically due to a complete anc power failure to all reactor coolant pumps or manually at any time desired. The automatic operation is cono sidered to be the normal operation of this system while the manual opero ation is considered as "Special or Infrequent" and is discussed under that" heading in section 8.3 .4 .

8.3.1.2 During normal plant operation the Decay Heat Selector Switch is kept in the "AUTO" position and its green light will be illuminated, indicating that motorooperated gate valve $11-\mathrm{HL} 2-1$ is closed.

8.3.1.3 When all power relays for the motor circuits of the reactor coolant pumps are opened the control circuit to doc motor ooperated isolation valve II-HI20I is completed and the valve is opened. As soon as the valve begins to open the green light will go. out. The red light will be illuminated when the valve is fully open. When valve $11-H 12-1$ is open the steam relief valve, $11-\mathrm{H}_{1} \mathrm{~S}_{-1}$, is connected to the steam line from the No. 2 steam generator. Although the reactor has been scrammed decay heat is being continuously added to the secondary water in the stoam generators 
and, since the turbine throttle valves have also closed; the steam pressure will begin to increase." When it reaches approximately 707 psia the steam relief valve will. Iift, allowing heat to be dissipated to the atmosphere.

\subsubsection{RUNNING}

8.3.2.1 As mentioned above, immediately following the loss of power, the turbine throttle valves close and the reactor control rods are dropped into the core. The reactor plant temperature thon begins to rise due to the relatively large. amount of heat still being generated by the reactor and to the sudden decrease in the coolant flowrate caused by pump coastdown, which in turn results in a decrease of the amount of hoat being transferred in the boilers. During the first fiew seconds after an accident, much of the decay heat is absorbed by the reactor coolant and the plant metal or is lost by radiation. The remainder is carried to the boiler heat exchangers where it is transferred to the water on the second. ary side of the boilers. The transfer of this heat to the secondaxy water reduces the temperature of the reactor coolant in the steam genero ators, thereby causing a density difference between the coolant at the boiler inlet and that at the boiler outlet. As a result of this density difference, and also due to the elevational difference beiween the boilers. and the reactor, natural circulation of the coolant thru the ioops is established and the operation becomes continuous. The heat transferrod to the secondary water causes the pressure of the steam in the boiler steam drums and interconnecting piping to increase until it reaches the sot pressure of the steam relief valve, $11-H 15-1$. At this time the relief valve opens and steam is blown to the atmosphere, thus removing heat from the plant. In effect, the boilers act as heat sinks to absorb the reactor decay heat.

8.3.2.2 The operation of the boilers as heat sinks, in conjunction with the steam relief valve discharge, will limit the temperature rise of the reactor coolant. In turn, the expansion of the coolant will also be limited to such a degree that the surge volume will, not cause the pressur. izer pilot-operated relief valve to open. The set pressure of" the steam relief valve, $1.1-\mathrm{HI} 5-1$, is based on calculations which include a domon. stration that the limiting temperature, as described abovo, is not reached in the Reactor Coolant System before the steam relief ralve begins to lift. These calculations are included in Appendix ${ }^{~} \mathrm{C}^{83}$.

8.3.2.3 The Decay Heat Removal System has been designed on the basis that no corrective action by plant personnel is required for at least two hours. However, the emergency diesel generator should be placed in service as soon as possible to operate, when necessary, one charging pump for adding water to the steam drums and to the pressurizer. 
8.3.2.4 Primary grade water from the Primary Water Storage Tank can be added to the boilers during a loss of a-c power by utilizing one charging pump, which can obtain its power. from the emergency diesel generator, and the crossover line between the Coolant Charging System and the Boiler Feedwater System. The detailed description of the procedure used for operating a charging pump for this service is contained in system Description No. 3, "Coolant Charging System". In order to line up the charging pump with the crossover line it is necessary to open only valve 08-HI6-39 in Auxiliary Equipment Room No. Is since, valve 1I-HI6-I is normally open. When the valving is properly aligned and the charging pump is operating, primary grade water will pass through the boiler foedwater regulating valves and into the boiler steam drums." Should the quantity of water pumped into the boilers be sufficient to cause the feed-water regulating valves to close, the charging pump discharge pressure will increase to approximately $1200 \mathrm{psig}$ and then the water relief valve, 11-H15-2, will open to prevent excessive pressure from being applied to the boiler feed piping. However, by attentive operation of the charging pump it is possible to prevent the water relief valve from lifting. The feedwater regulating valves will be operable at this time since they may also draw their power from the emergency diesel generator.

8.3.2.5 The reactor continues to generate decay heat at a decreasing rate during the emergency and eventually the heat losses by radiation will. become equal to the decay heat rate. After this time the coolant tompor ature will decrease and, as a consequence, the volume of the coolant will also decrease. The steam relief valve is sized to prevent the water level in the pressurizer from dropping below the zero point of the level indicator. Unless a water level is maintained in the pressurizer there may be no natural convection circulation of coolant and boiling may occur in the reactor. Should it be desired to raise the pressurizer water lovel. a charging pump may be used in the manner normally incorporated for primary system charging.

\subsubsection{STOPPING}

8.3.3.I If amc electrical power is returned to the reactor coolant pumps while the Decay Heat Removal system is in operation the plant operating personnel should take steps to establish a normal hot shutdown procedure, provided the reactor coolant temperature is still high enough for such move. If this is not possible the normal cold shutdown procedure should be followed.

8.3.3.2 After the Decay Heat Removal System has completed its automatic operation, acc power has been restored to the plant, and the station start-up has begun, with steam flow estabilished to the turbine, the Decay Heat Selector Switch is turned to the "CLOSE" position and left there until the green light illuminates indicating that the motor operated isolation valve is closed. The selector switch is then turned to the "AUTO" 
position so that the Decay Heat Removal System will again be placed in readiness for normal, automatic operation.

\section{$\therefore 8.3 .4$ SPECIAL OR INFREQUENT}

8.3.4.1 The Decay Heat Removal System may be utillzed for removing decay heat following a normal station shutdown in which complete cooldown is not necessary or desirable, i.oe maintaining the reactor at low powso levels with no turbine demand. Such a condition would exfist whon the station is shut down for an over night capacity reduction. This method of operation would be done with normal asc power available at the station.

8.3.4.2 The detailed operating procechure for a station shutdown for capacity reduction can be found in the Shippingport Power Station Manual; . Volume ImChapter 45, "Station Shutdown". In essence, the procedure involves reducing the turbinemgenerator load to approximately $10 \mathrm{MW}$, shifting the station service to the network, further reducing the load to $\odot \mathbb{M W}$, and then opening the generator breaker. At this time the turbine is turning at no load synchronous speed. The Decay Heat Selector Switch is next set on "OPEN" causing the motoroperated isolation valve to open。 The turbine throttle valves are then closed and the reactor is shut dom. The steam relief valve, $11-H I 5-1$, will alternately open and close, thoroby discharging steam, and thus decay heat, to the atmosphere. The normal water level in the boilers is maintained by means of the boiler feed pumps..

8.3.4.3 When the station is being returned to service after a hot shut down, the motoroperated isolation valve should be closed after steam flar to the turbine has been established. The Decay Heat Selector Switch should then be placed in the "AUTO" position.

8.3.4.4 There may be occasions when it is desired to affect a station hot. shutdown in order to perform maintenance on some portion of the sibam system downstream of the steam lines manual stop valves. Since the Decay Heat Removal System steam relief valve is also downstream of one of these valves it is apparent that the relief valve will be out of service at this time. To remove decay heat under these conditions steam is dumped from the boilers through the boiler vent lines by manual operation of the valves in those lines.

8.3.4.5 Since the motor ooperated isolation valve, $11-102-l_{2}$ is remotoly operable from the Main Control. Room, the decay heat steam reliof valve, $I I-H I 5-I_{2}$ may also be used to facilitate plant operation at low reactor power levels. 


\title{
8.3.5 EMERGENCY
}

8.3.5.1 Emergency operation of the Decay Heat Removal System is considered to be the normal service of the system and is described in sections $8.3 .1,8.3 .2$, and 8.3 .3 .

\subsection{Safety Precautions}

\author{
8.4.1 HAZARDS
}

8.4.1.1 Should the decay heat relief valve stick open. when it is being used during plant operation at low power levels, a rapid transient may occur in the primary systems. This could possibly result in permanent damage to some of the primary system components.

\section{4 .2 PRECAUTIONS}

8.4.2.1 To obviate the possibility of a rapid transient in the Reactor Coolant System, as described in paragraph 8.4.1.1., the reactor coolant temperature should be observed closely and prevented from dropping to a dangerous value by closing the motoroperated isolation valve to the decay heat steam relief valve.

8.4.2.2 Although the Decay Heat Removal System is designed to function properly without the assistance of emergency power for two hours after the loss of reactor coolant pump power, the emergency diesel generator should be placed into service as soon as possible to avoid any last minute delays which may jeopardize the operation of the system.

8.4.2.3 Care must be taken that the stop valve, $11-H 16-1$, in the crossover line is not inadvertently closed when a charging pump is needed for adding make up water to the secondary side of the boilers during a loss of coolant pump power accident.

8.4.2.4 Since most water relief valves do not have reliable reo seating characteristics, an effort should be made to stop the charging pump being used for boiler makeup, after the boiler feedo water regulating valves have closed. In this manner it is possible to prevent the pressure in the crossover line from reaching the set pressure of the relief valve. 
8.4.2.5 It. must be remembered during an incident involving the loss of all electrical power to the reactor coolant pumps that, in time, it will be necessary to charge water to. the Reactor Coolant System. For this reason, the level in the pressurizer should be observed and the necessary steps taken to line up a charging pump before the low level limit is reached in the pressurizex。

\subsection{Preventative Maintenance}

8.5.1 The condition of both the water relief valve and the steam relief valve should be checked periodically to be certain that at all times in readiness for operation.

8.5.2 The motor operated gate valve, 1 I $\mathrm{HI} 2-1$, should be checked occasionally for proper operation. 


\section{APPENDIX A}

Component list

Component

Name \& Number

Motor-Operated

Gate Valve,

1I-HI2-I

Steam Relief Valve,

II-HI5-I

$\frac{\text { E-Spec.No。 }}{565259}$

Water Relief

Valve,

$11 \infty \mathrm{H} 15-2$

Manual Gate

Valve;

II-HI6-I
569279

order

Number

Walworth Co. $\quad 73-81116$

Crosby Steam 73-100585 Gage \& Valve Co.
Manning, Maxwell, 73-81315 \& Moore

565474

Pacific Valve Co. 73-59302.

565278 


\section{APPENDIX B}

Decay Heat Removal System

System Design Data Summary

I. System Data

1. Flowrate $\quad-2.0 \times 10^{5} \mathrm{Ib} / \mathrm{hr}$ per loop (estimated)

2. Maximum Coolant Temperature Rise $-5.4^{\circ} \mathrm{F}$

II. System Piping

A. Crossover Iine

1. Size $-3^{\text {th: }}$

2. Schedule and material - sch. 80 carbon steel

III. Components

A. Steam Relief Valve

1. Setting -- 707 psia

2. Flowraté $\quad-3 j, 600 \mathrm{lb} / \mathrm{hr}$

3. Accumulation - $6 \%$

4. Blowdown - $4 \%$

B. Water Relief Valve

1. Setting - 1200 psig

2. Flowrate - $50 \mathrm{gpm}$

3. Accumulation - $20 \%$

4. Blwodown - 5\%. 


\section{APPENDIX C \\ Supporting Calculations}

1. Adequacy of Water Volume in Boilers to Dissipate Reactor Heat for Two Hours After the Start of an Accident.

It is assumed that the decay heat from the reactor is used to heat (1) the reactor coolant $5 \%$ F, (2) the primary plant metal $50 \mathrm{~F}_{2}$ (3) the boiler metal $180 \mathrm{~F}$, (4) the boiler water $180 \mathrm{~F}$, and that the remainder of the decay heat will be used to vaporize secondary water in the boilers at $504 \mathrm{~F}$. Radiation losses have been neglected.

The heat required to raise the reactor coolant temperature from $527^{\circ} \mathrm{F}$ - to $532^{\circ} \mathrm{F}$ 'is: $\mathrm{B}$. T.U.

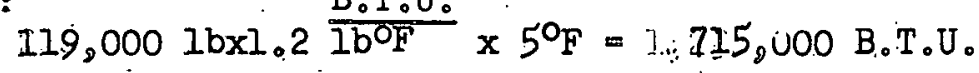

The heat required to raise the primary plant metal temperature by $50 \mathrm{~F}$ is:

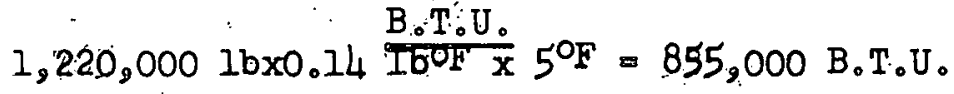

The heat required to raise the temperature of the secondary water from $486^{\circ} \mathrm{F}$ to $504^{\circ} \mathrm{F}$ is: B.T.U.

$$
86,600 \mathrm{Ibxl} .2 \overline{16^{\circ} \mathrm{F} \times} 18^{\circ} \mathrm{F}=1,820,000 \mathrm{~B} . \mathrm{T} . \mathrm{U} \text { 。 }
$$

The heat required to raise the temperature of the boiler metal from $486^{\circ} \mathrm{F}$ to $504 \mathrm{O}^{\mathrm{F}}$ is: $\mathrm{B} . \mathrm{T}_{0} \mathrm{U}$.

$$
279,0001 \mathrm{bx0} .14 \frac{160 \mathrm{~F}}{\mathrm{~K}} 18^{\circ} \mathrm{F}=\mathrm{I}, 704,000 \mathrm{~B} \cdot \mathrm{T} \cdot \mathrm{U} \text { 。 }
$$

The sum of the above values, which is the total heat absorbed by the plant is $4,044,000 \mathrm{~B} . \mathrm{T} . \mathrm{U}$.

The total reactor heat output during the first two hours after an emergency shutdown from full power is $2.81 \times 10^{7} \mathrm{~B} . \mathrm{T} . \mathrm{U}$. Hence the heat available for vaporizing the secondary water in the boilers is $2.81 \times 10^{7}$ B.T.U. $_{0}-4.14 \times 10^{6} \mathrm{~B} . \mathrm{T}_{0} \mathrm{U}_{0}$ or $2.396 \times 10^{7} \mathrm{~B} . \mathrm{T} . \mathrm{U}$ 。

The latent heat of vaporization of saturated water at $504^{\circ} \mathrm{F}$ is approximately $710 \mathrm{BTU} / \mathrm{lb}$. The amount of boiler water evaporated in two hours is, then:

$$
\frac{2.396 \times 10^{7} \mathrm{~B}_{0} \mathrm{~T}_{0} \mathrm{U}_{0}}{\frac{\mathrm{B}_{0} \mathrm{~T}_{0} U_{0}}{\mathrm{Ib}}}=3.38 \times 10^{4} \mathrm{Ib}
$$

The total secondary water weight in the four boilers is $86,600 \mathrm{lb}$.

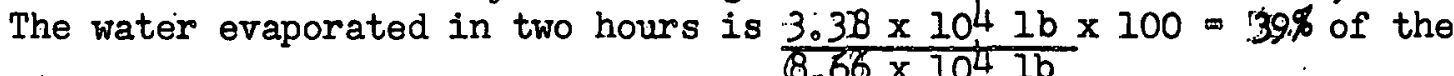
total secondary water. The Decay Heat Removal System is designed on the assumption that a charging pump will be available for supplying feed- 


\section{Appendix C (contid)}

water to the boilers two hours after an emergency shutdown. On this basis, the volume of secondary water in the boilers is considered adequate during a loss -0 fflow accident。

\section{Determination of Relief Valve Setting}

In order to ensure natural convection flow during a loss of a-c power accident the reactor "coolant loops must be maintained full of water at all times. This requisite can be met by making certain that a water level is always noticeable in the pressurizer. Hence, the heat sink must not be permitted to continue dissipating enough decay heat to cause a decrease in the average coolant temperature which would result in a coolant coritraction sufficient to drop the pressuro izer water level almost to the zero point of the level indicator. Based on the vendor ${ }^{8} s$ drawings, it is estimated that the water volume in the pressurizer from the surge line inlet port to the low level alarm point is approximately $88 \mathrm{cu}$.ft. By providing a safety allowance of $8 \mathrm{cu}_{\circ} \mathrm{ft}_{\circ}$ it is assumed that $80 \mathrm{cu}$.ft。 of reactor coolant, initially at $636 \circ$, may be added to the loops during a loss of a c power accident before the heat sink must cease operating.

This contraction of $80 \mathrm{cu}$ oft. of water will. cause the primary system pressure to drop to about 1800 psig. Since the saturation temperature corresponding to $1800 \mathrm{psig}$ is 621 . $\mathrm{F}_{\text {, }}$ this will be the temperature of the $8 \mathrm{cu}$.ft. of water remaining-in the pressurizer。 The weight of this water is $324 \mathrm{lb}$. The weight of the initial. $88 \mathrm{cu}_{0}$ $\mathrm{ft}$, at $636^{\circ} \mathrm{F}$, is $3420 \mathrm{lb}$. Hence the weight of the water added to the reactor coolant assumed that the total volume of loops from the pressurizer is $3096 \mathrm{lb}$. The total volume of reactor coolant in the four loops and the reactor vessel is $2465 \mathrm{cu}$.ft. The weight of this water is $118,630 \mathrm{Lb}$. Then, the total weight of water in the primary system at the time the relief valve must close is $30961 \mathrm{~b}+118,630$ $1 \mathrm{~b}$ 。 or 121.,726 $\mathrm{lb}$. The density of the reactor coolant at this time is $2465 \mathrm{cu}_{0} \mathrm{ft}_{0}$ or $0.0203 \mathrm{cu}$.ft。/1.b. From Ellenwood and Mackey Charts, $121,7261 \mathrm{~b}$ 。

the average water temperature corresponding to. a pressure of $1800 \mathrm{psig}$ and a specific volume of $0.0203 \mathrm{cu}_{0} \mathrm{ft}_{\mathrm{o}} / \mathrm{Ib}$ is approximately $504 \mathrm{~F}$.

This, then, is the minimum average reactor coolan't temperature which can be permitted by the Decay Heat Remoral System. Since the temperature of the steam will be about $3-4^{\circ} \mathrm{F}$ less than the average coolant temperature at this time, the steam temperature will be approximately $5000 \mathrm{~F}$ when the steam relief valve should close. The saturation pressure corresponding to this temperature is 680 psia. Since the relief valve being used as the heat sink has about $4 \%$ blow down it should be set at (680 psia)x(1.04) or 707 psia. 
Appendix C ( cont $^{8} \mathrm{~d}$ )

\section{Determination of Required Heat Sink Rating}

A. When purchased, the decay heat valve used as the heat sink by the Decay Heat Removal System was actually sized on the following assumptions:

a. Natural convection coolant flowrate will be 150 gpm per loop during a loss $\rightarrow$ of $=$ flow accident. A more accurate estimated flow-rate, based on actual conditions is determined in part 4 of this appendix.

b. The pressure drop through a reactor coolant loop was estimated to be $0,0.32$ psi. at a flow of $150 \mathrm{gpm}$.

c. The boiler heat transfer coefficient was approximated as $22 \frac{\mathrm{B}_{0} \mathrm{~T} \cdot \mathrm{U}}{\mathrm{hr} \cdot \mathrm{f}^{2}} \mathrm{~F}_{\mathrm{F}}$, assuming that "U" valves are proportional to the 0.8 power of the velocity.

The following equation can then be used to determine the thermal. driving head across a boiler.

$$
\text { where: } \begin{aligned}
\Delta P & =\frac{H \cdot \Delta P}{144} \\
\Delta P= & \text { loop pressure drop, } 0032 \text { psi } \\
H= & \text { effective elevational difference between heat } \\
& \text { source and heat sink, } 1.3 \mathrm{ft} \text {. } \\
\Delta \rho= & \text { density difference between the hot and cold } \\
& \text { legs of a loop, } \# / \mathrm{ft}^{3} .
\end{aligned}
$$

From Ellenwood charts, a relation between density difference and temperature difference, at constant pressure, ${ }_{2}$ can be devieloped. Thi.s expression is

$$
\Delta \rho=0.065 \Delta \mathrm{m}
$$

Substituting in the above equation and solving for $\Delta \mathrm{T}$ yields

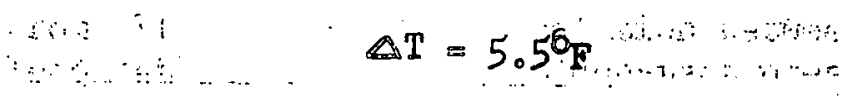

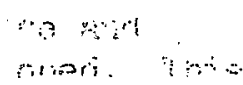

Assuming the cold leg reactor coolant temperature is $525^{\circ} \mathrm{F}$, the $\log$ mean temperature" difference, for a steam temperature of $504 \mathrm{OF}_{8}$ will be $24{ }^{\circ} \mathrm{F}$. The rate of heat transfer across a boiler, using a mean. heat transfer area, is then

$$
\begin{aligned}
Q & =U A(L M T D)=22 \frac{B_{0} T_{0} U_{0}}{f t^{2} \text { oF hro }} \cdot 8700 \mathrm{ft}^{2} \cdot 24 \mathrm{O}^{\mathrm{T}} \\
& =4,600,000 \frac{\mathrm{B}_{0} \mathrm{~T}_{0} \mathrm{U}_{0}}{\mathrm{hr}}
\end{aligned}
$$




\section{Appendix C (cont $\left.{ }^{\circ} \cdot d\right)$}

It is now necessary to determine the heat required to raise the secondary side temperature to $504 \%$, the saturation temperature corresponding to the rsetting of the decay heat relief valve.

$$
Q=\left(m_{2} c_{1}+m_{2} c_{2}\right) \cdot \Delta T
$$

where:

$$
\begin{aligned}
Q= & \text { heat required, } B_{0} T_{0} U_{0} \\
m_{1}= & \text { mean water weight, } 21,600 \mathrm{lb} \\
c_{1}= & \text { specific heat of water } 12 \frac{\mathrm{B}_{0} \mathrm{~T}_{0} \mathrm{U}_{0}}{\mathrm{Ib} \mathrm{OF}} \\
\mathrm{m}_{2}= & \text { mean metal weight, } 69,700 \mathrm{lb}, \\
\mathrm{c}_{2}= & \text { specific heat of metal, } 0.14 \frac{\mathrm{B}_{0} \mathrm{~T}_{0} \mathrm{U}_{\circ}}{1 \mathrm{~b} O \mathrm{~F}} \\
\Delta \mathrm{T}= & \text { temperature change of metal and water, } \\
& 18^{\circ} \mathrm{F},\left(504{ }^{\circ} \mathrm{F}-486^{\circ} \mathrm{F}\right)
\end{aligned}
$$

then $Q=643,000 \mathrm{~B}, T_{0} U_{0}$

The time required to heat the secondary side to $504^{\circ} \mathrm{F}$ can be deter. mined as follows:

$$
\frac{643,000^{\circ} B_{0} T_{0} U_{0}}{4,600,000 \frac{B_{0} T_{0} U_{0}}{h r}} \times 3600 \frac{\mathrm{sec}}{h r}=504 \mathrm{sec}
$$

From the decay heat curve, Fig. 8.3 , the reactor will be at approximately $1.8 \%$ power 504 seconds atter scram. Since the maximum capability of the core is $349,000 \mathrm{kw}$, the reactor will be adding $0.018 \times 349,000 \mathrm{mw}$, or $6300 \mathrm{kw}_{3}$ of heat to the plant at this time. On this basis the decay heat relief valve is rated at $7000 \mathrm{kw}$.

Since the latent heat of vaporization of saturated water at 707 psia is approximately 710 B.T.U./1b。 the relief valve must be capable of passing

\section{$\frac{\left.7000 \mathrm{kw} \times 3 \mathrm{LL}_{1}\right] 3 \mathrm{BTU} / \mathrm{kw} \mathrm{hr}}{710 \mathrm{BTU} / \#}$}

or 33,600 lbs. of steam per hour.

The adequacy of the heat sink rating, however, cannot be based solely on the above analysis. The Decay Heat Removal System accomplishes its primary purpose of preventing damage to the core during a loss $m$ of $m a_{\infty} c_{\infty}$ power accident by establishing a satisfactory flow thru the reactor. This flow would be stopped if enough primary water were lost to lower the water level in the reactor vessel below the outlet nozzle. For this reason the restriction is placed on the system that primary relief valves must not be caused to lift. This 
e!

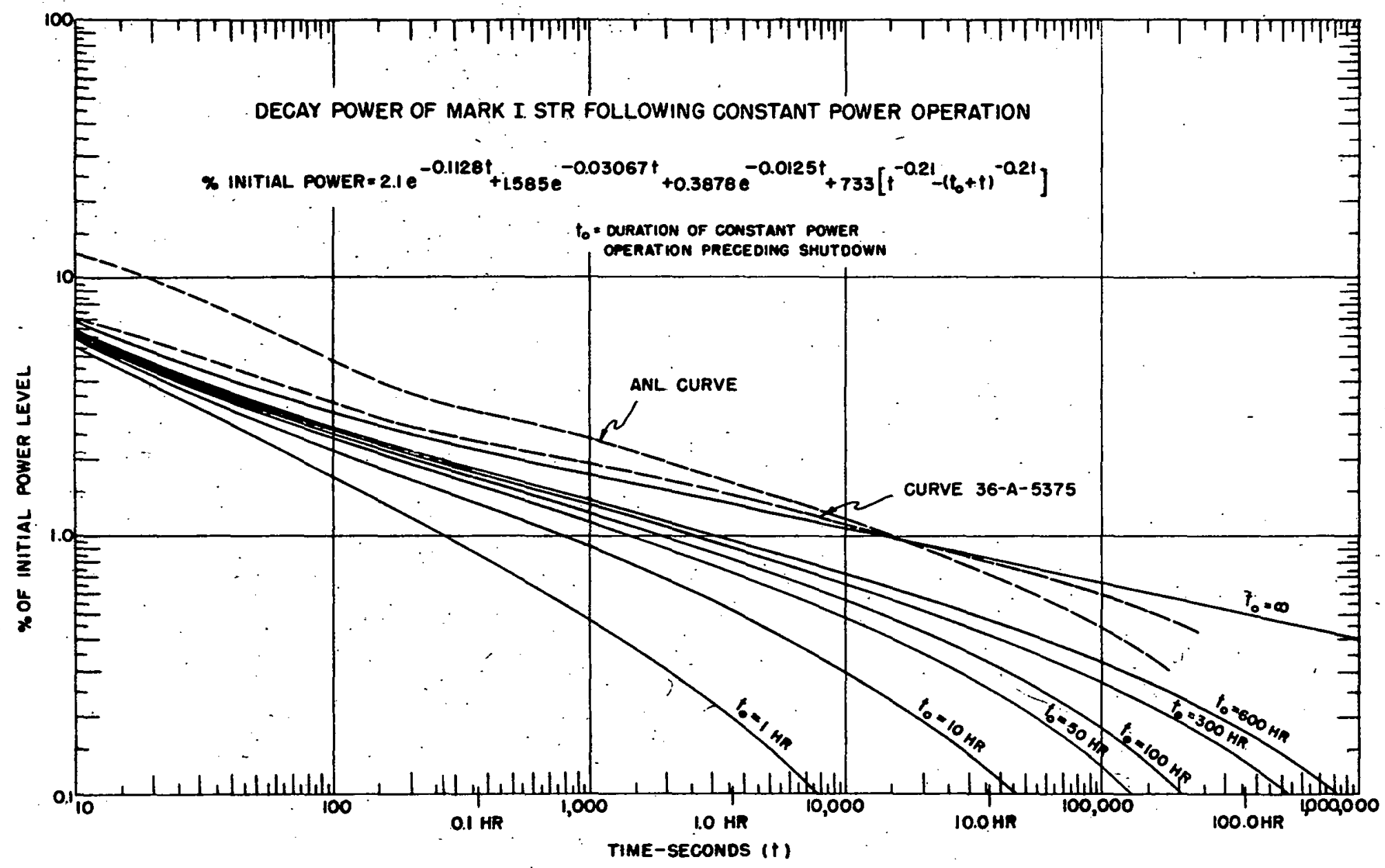




\section{Appendix C ( cont $\left.^{\mathbb{d}} \mathrm{d}\right)$}

is done by preventing the primary plant average temperature from increasing to the point where the resulting surge causes the primary pressure to exceed the lowest primary relief valve setting. Pressur. izer calculations have determined the limiting primary plant average temperature increase to be $7^{\circ} \mathrm{F}$. Therefore, it is necessary to show that, when the secondary side average temperature has reached $504^{\circ} \mathrm{F}$, the primary plant average temperature has not yet increased $7^{\circ} \mathrm{F}$.

A heat balance may be written on the plant at the instant just prior to the operation of the decay heat relief valve. The equation for this heat balance is:

$$
Q_{0} \cdot q_{t}-Q=K_{I}\left(T_{S_{\theta}}-\dot{T}_{S_{i}}\right)+K_{2}\left(T_{\theta}-I_{i}\right)
$$

where: $\quad Q_{0}=$ Operating level of reactor prior to scram, 331,000 BTU

$\left.q_{t}=\int_{t}^{\infty} \frac{Q_{t}}{Q_{c}} t\right) d t$, which can be evaluated for any. after scram by curve \#398812.

$Q_{R}=$ Thermal radiation losses, $232 \frac{\mathrm{B}_{0} \mathrm{~T}_{0} \mathrm{U}_{0}}{\text { sec }}$ $\begin{aligned} \theta & =\text { Time after scram, } 504 \text { sec。 } \\ \mathrm{K}_{1} & =\text { Secondary system heat capacity, } 1.43 \times 10^{5} \\ \mathrm{~T}_{\mathrm{s}_{\theta}} & =\text { Secondary temperature at time } \theta, 504 \mathrm{O}_{\mathrm{F}}\end{aligned}$

$\mathrm{T}_{\mathrm{S}_{i}}=$ Initial secondary temperiture, $486^{\circ} \mathrm{F}$

$K_{2}=$ Primary system heat capacity, $3.14 \times 10^{5} \frac{\mathrm{B}_{0} \mathrm{~T}_{0} \mathrm{U}}{\mathrm{O}_{\mathrm{F}}}$

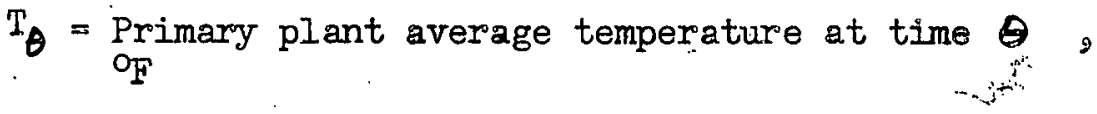

$\mathrm{T}_{i}=$ Initial primary plant average temperature, $\mathrm{O}_{\mathrm{F}}$

Solution of this equation yields a primary plant average temperature increase of $5.4 \circ \mathrm{F}$ from the instant of scram to the time when the decay heat relief valve lifts. The rating of the heat sink is, therefore, satisfactory. 


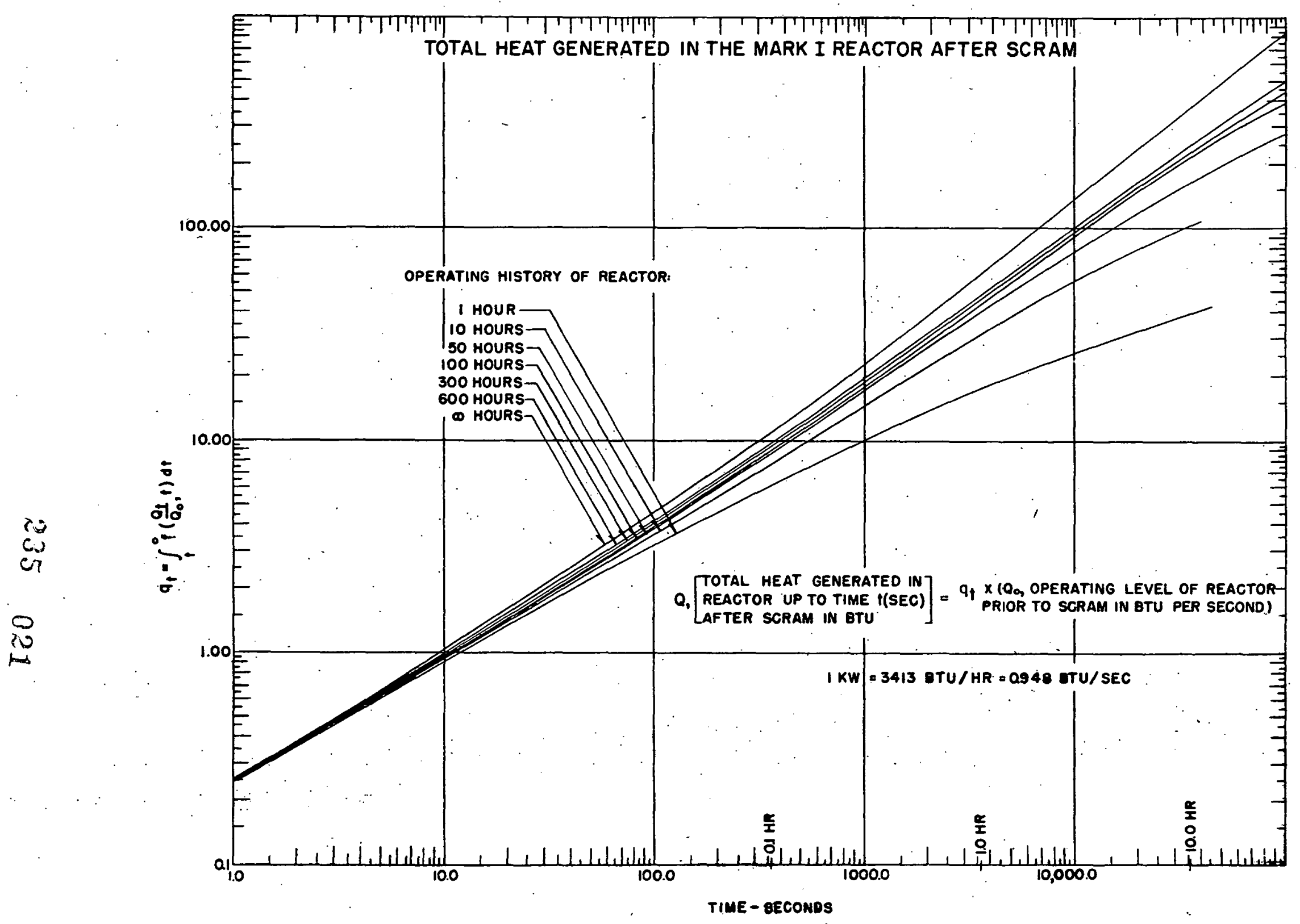

GURVE NO. 398812 
4. Determination of Natural Convection Reactor Coolant Flow-rate During a Loss of amc Power Accident

Detailed calculation of the decay heat removal netural convec. tion coolant flow-rate involves the development of an accurate pressure drop curve as a function of flow through the primery loops, for low flows. This curve can be determined by summing the individual pressure drops thru the reactor and thru the piping, fittings and components in the loop, for several low flows.

Table $I$ is a tabulation of the factors used to evaluate the individual pressure losses around a primary loop. The values for the pipe and fittings are based on information presented in WAPD $\triangle$ PA. 415, dated Feb. 14, 1956 and titled "Calculation of PWR Primary Loop Pressure Drops, Issue 2"。

\section{Table I}

Reactor Coolant Loop Pressure Losses (Based on a loop with a B \& W boiler)

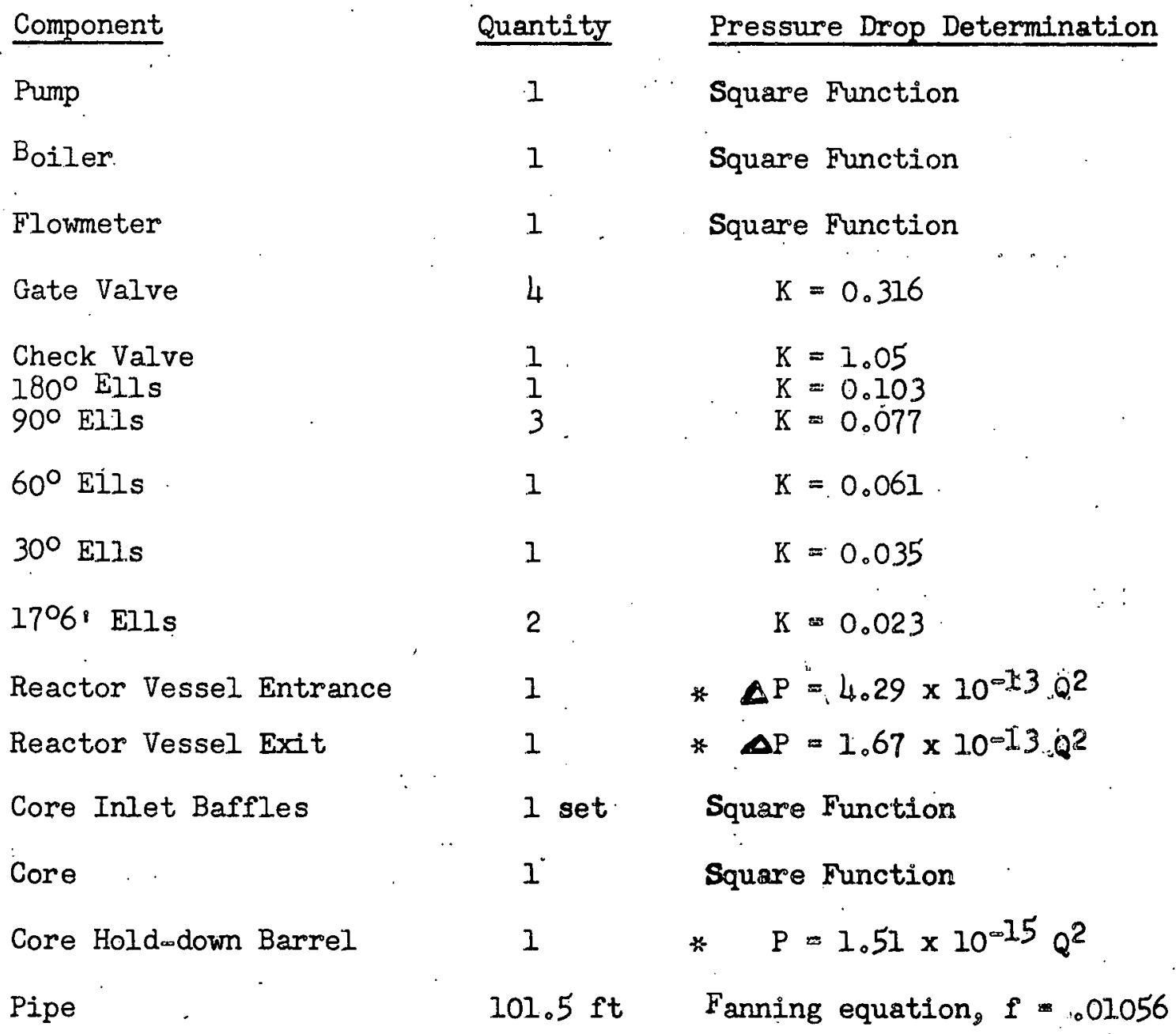

* where $\Delta P=$ pressure drop, ft

$\mathrm{Q}=$ flow, $\mathrm{lb} / \mathrm{hr}$ 


\section{Appendix C ( cont $\left.^{\circ} \mathrm{d}\right)$}

The curve of pressure drop thiru a primary coolant loop vs. cool on ant flow-rate, using the up-to-date valves listed above, is presented in Fig. 8u2. The difference between the pressure drop thru a loop containing a Babcock \& Wilcox boiler and that thru a loop containing a. Fosterwheeler boiler is assumed negligible at the low flows involved.

The equation of the curve in Fig. 8-2 is:

$$
\Delta P=3.66 \times 10^{-12} W^{2}
$$

where: $\quad \Delta P=$ total loop pressure drop, psi

$$
W=\text { loop floworate, } 1 \mathrm{~b} / \mathrm{hr}
$$

The natural convection coolant flow-rate when the decay heat is just equal to that being dissipated by the heat sink can be deter o mined by equating the above pressure drop to the thermal driving head. This yields

$$
3.66 \times 10^{-12} W^{2}=\mathrm{H} \frac{\Delta \rho}{144}
$$

where: $\quad H=$ the effective elevational difference between the heat source and the heat sink, ft. $\Delta P=$ density difference between the hot and cold legs of a loop, lb/cu。ft。

By use of the Ellenwood and Mackey charts, the density difference may be expressed as a function of the temperature difference, at a constant system pressure, by the following" relation:

$$
\Delta P=P_{\mathrm{H}} \quad \rho_{\mathrm{C}}=0.065 \Delta \mathrm{T}
$$

However, $\Delta \mathrm{T}$ can also be expressed as

$$
\begin{aligned}
\Delta T & =\frac{Q}{W C} \\
\text { or: } & \Delta P=0.065 \frac{Q}{W C}
\end{aligned}
$$

Substituting this in the pressure balance yields:

$$
3.66 \times 10^{-12} W^{2}=\frac{H \times 0.065}{144} \times \frac{\theta}{W c}
$$

This reduces to: $3.66 \times 10^{-12} \mathrm{~W} 3=4.9 \times 10^{-3} \mathrm{Q}$ 
Pres mre toss vs, Reactor Coclant, loop flow during a loss of -power accident

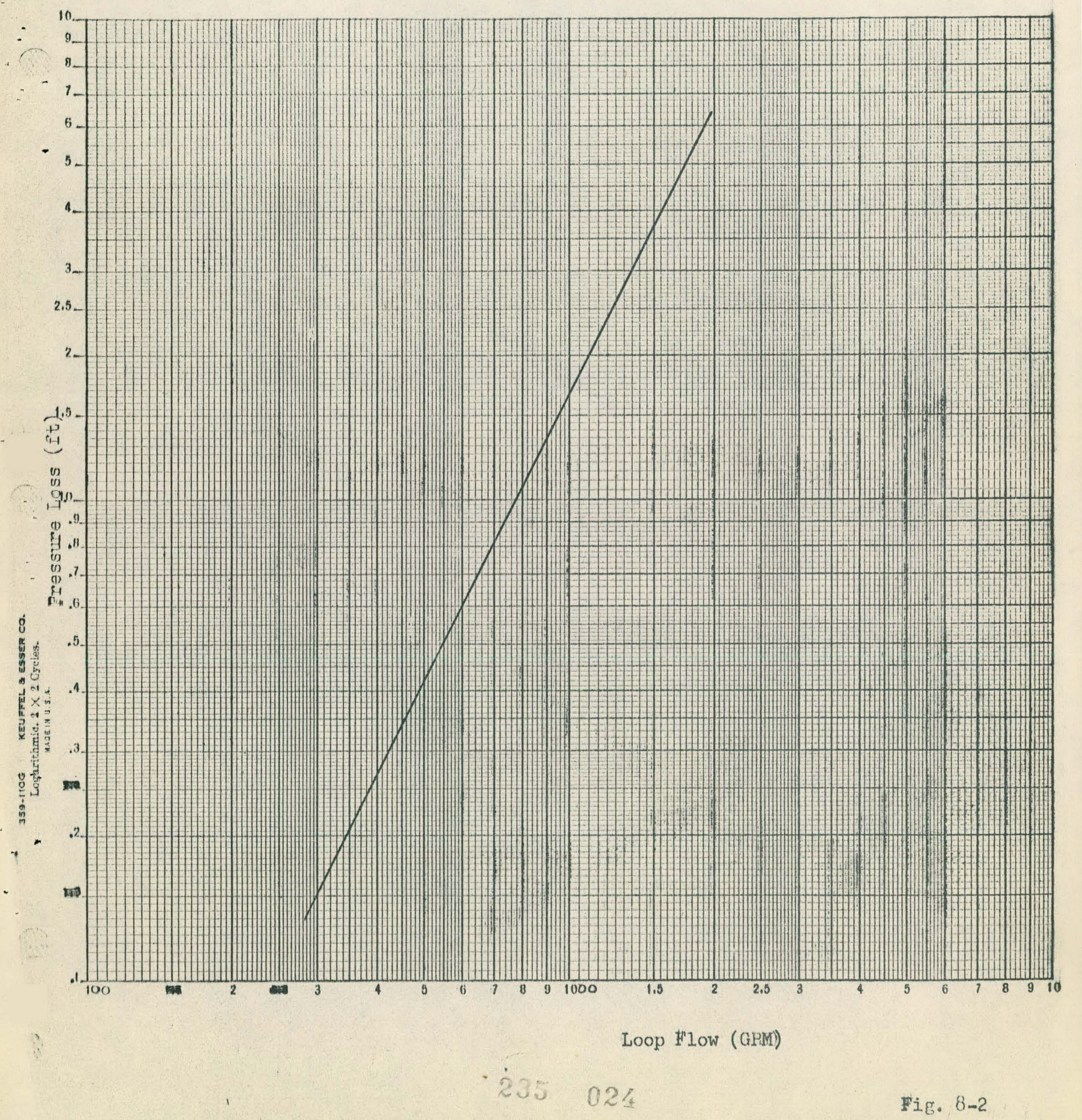




\section{Appendix C (contid)}

The solution of this equation predicts that the natural cono vection coolant flow rate during a loss-of-a-c power accident will be approximately $2.0 \times 10^{5} \mathrm{lb} / \mathrm{hr}$ per loop when the heat sink is removing its full rated capacity。

As reported in WAPD $\mathrm{RDa}-114$, dated 0ct. 5,1955 , a convective flow rate of $1.0 \%$ full flow is sufficient to satisfactorily protect the reactor core after the loss of flow. A decay heat removal coolant flow-rate of $2 \times 10^{5} \mathrm{lb} / \mathrm{hr}$ per loop is equivalent to

$$
\frac{4 \times 2 \times 10^{5}}{28.35 \times 10^{6}} \times 100=2.8 \% \text { of full flow。 }
$$

Hence, the Decay Heat Removal System is capable of satisfactorily performing its primary function of preventing damage to the core after an emergency shut-down caused by the loss of electrical power to the main coolant pumps.

Although the above analysis does not include a complete transient study of reactor coolant flow rates throughout the duration of the accident, it is based on the results of a transient analysis con ducted to assist in the design of the PWR Emergency Cooling Systen which was the predecessor of the Decay Heat Removal System. The transient analysis was based on plant parameters whose values have changed somewhat since that work was done. The basic procedure used above to estimate the natural convection coolant flowiate is identi. cal to that used in the transient analysis except that current values are used for the plant parameter's involved and an estimated flow rate is determined only for the time during which the steam relief valve is passing its full rated capacity。

For purposes of comparison, a copy of the original report which contained the results of the transient analysis used in the design of the Emergency Cooling System is herewith attached. 


\section{APPENDIX}

The design of the PWR Emergency Cooling System has evolved from a series of calculations, continually being refined as plant parameters such as piping arrangement and component design become finalized. The present design has progressed through two stages of calculations.

To illustrate the engineering techniques utilized in this system ${ }^{0}$ design, the following details the method employed in each step:

\section{Preliminary Phase}

\section{A. Condenser Rating}

After determining that the PWR Emergency Cooling System should bo a buffer fluid type system involving three circuits, reactor coolant, secondary steam and cooling water, the first step in its design was to approximate the required design rating of the system's beat sink. This was done with a limited amount of information about the plant $e_{\circ} g_{\circ}, g$ such parameters as maximum plant capability (reactor output), approximate total water and metal volume and mass, pump curve, etc。 were known.

A heat balance was written on the primary plant at any time, after a scram.

$$
\frac{\text { Qo } \left.q t-Q_{S} \theta-Q_{P} \theta-K_{1}\left(\bar{T}_{1}\right)-T_{s i}\right)}{W_{M} C P_{M}+W_{C} C P_{C}}=\bar{T}_{\theta}-T_{i}
$$

Reactor Heat Output - Heat Removal - Thermal Radiation Losses Heat to Steam Circuit

\section{Plant Heat Capacity}

Average Plant Temperature Change

where $Q_{0}=$ Operating level of reactor prior to scram; BTU/Sec

$$
\begin{aligned}
& q_{t}\left.=\int_{t}^{f} \frac{q_{t}}{Q_{0}}, t\right) d t \\
& \text { which can be evaluated from curve } 398812 \\
& Q_{S}=\text { Rating of heat sink, BTU/Sec。 } \\
& Q_{T}=\text { Radiation Iosses; BTU/Sec。 } \\
& \theta=\text { Time after scram; seconds } \\
& W_{M}=\text { Weight of metal in plant, Ibs。 } \\
& \mathrm{CP}_{\mathrm{M}}=\text { Specific heat of metal, BTU/Ib } \mathrm{O}_{\mathrm{F}}
\end{aligned}
$$




$$
\begin{aligned}
& W_{C}=\text { Weight of water in plant, Ibs。 } \\
& \mathrm{CP}_{\mathrm{C}}=\text { Specific heat of water, } \mathrm{BTU} / \mathrm{Ib} \mathrm{F} \\
& \bar{T}_{i}=\text { Average plant temperature prior to } \operatorname{scram}_{9} O_{F} \\
& \overline{\mathrm{T}}_{\theta}=\text { Average plant temperature after } \theta \text { seconds after } \\
& \text { scram }{ }^{\circ} \text { F } \\
& \mathrm{T}_{\mathrm{Si}}=\text { Steam temperature prior to } \operatorname{scram}_{2} \mathrm{O}_{\mathrm{F}} \\
& \mathrm{K}_{1}=\text { Steam side heat capacity, } \mathrm{BTU} / \mathrm{O}_{\mathrm{F}} \\
& =W_{S} P_{S}+W_{M S} C P_{M S}
\end{aligned}
$$

By assuming various heat sink ratings, $\theta_{0} \mathrm{~g}_{0} 2000 \cdot \mathrm{kw}, 4000 \mathrm{kw}, 6000 \mathrm{kj}$, curves were plotted of average plant temperature excursions after scram. The peak temperature values taken from these curves are an indication of the maximum pressure surge which would result during the emergency pertod. The usual limiting factor in determining the sinks rating is the restriction that the pressure surge resulting from the average temperature change must not exceed the primary relief valve setting. For PWR the Lowest primary relief valve setting is $2205 \mathrm{psig}$ (the volume surge which would result in exceeding this value is $+16 \mathrm{ft}^{3}$ or approximately $+50 \mathrm{~F}$ rise)。

The results of these calculations are shown on curve 425122. (illustrated for the reference core).

As can be seen from the heat balance this analysis is approximate as the steam temperature is assumed equal to the average coolant temperature. However, this method has merits in that a fair estimate of the average temperature characteristics can be obtained with relatively little effort.

A more exact method of obtaining the steam temperature's relationship to the average coolant temperature for a controlled emergeney cooling system is detailed below.

B. Relationship Between Inducted Natural Convection Flow and the Elevational Difference Between Heat Source and Sink

To approximate the reactor coolant flow induced by the heat sink as a function of the elevational difference during emergency cooling, an equation of the following form can be developed by equating the thermal driving heat to the system pressure drop: *

* For this approximate method, the system pressure drop during emergency cooling flows can be found by ratioing the squares of the full flow condition to the low flow condition. 


$$
\mathrm{W}=\mathrm{K} / \frac{\mathrm{QH}}{\mathrm{CP}}
$$

where $\mathrm{W}=$ reactor coolant flowrate per loop induced by natural convection; $\mathrm{lb} / \mathrm{hr}$

$$
\begin{aligned}
K= & \text { system constant dependent on plant physical parameters; } \\
= & 495 \text { for PWR during emergency cooling conditions for the } \\
& \text { system pressure drop assumption }
\end{aligned}
$$

$$
Q=\text { heat sink rated capacity; per loop; BTU/hr }
$$

$\mathrm{H}=$ effective elevational differences between heat source and heat sink, $\mathrm{ft}$.

$\mathrm{CP}=$ specific heat of the reactor coolant $\mathrm{BTU} / \mathrm{Ib} \mathrm{F}^{\mathrm{F}}$

$$
\mathrm{n}=\text { approximately } 3
$$

The PWR Emergency Cooling System flow approximating equation is:

$\mathrm{W}=495^{3} \sqrt{\frac{\mathrm{QH}}{\mathrm{CP}}}$

By the use of this equation an order of magnitude for the reactor coolant flowrate can be determined.

At rated heat sink capacity $(1000 \mathrm{~kW} / \mathrm{loop})$ the predicted PWR natural convection flow by this method is equal to $1.55 \times 10^{5} \mathrm{lb} / \mathrm{hr}$. per loop.

In the next section, these approximations will be compared to the more exact calculations.

\section{Design Phase}

A. Natural convection Reactor Coolant Flowrate, Primary and Secondary

$\because$ Side Temperature Characteristics, Pressure and Volume Surges During Emergency Cooling

As the Reactor Coolant System's piping arrangement and the design of , the majority of components become firm, more detailed emergency cooling calculations can be undertaken.

This involves the development of a pressure drop curve for the primary loops as a function of low flows.

This curve can be developed by totaling the pressure drop around $a$ primary loop for a given flowrate as a summation of 211 pressure losses due to piping, fittings, component and reactor losses; $i_{0} e_{02}$

$$
\begin{aligned}
\Delta \mathrm{h} \text { (ft of fluid flowing) } & =\frac{\mathrm{fl \textrm {v } ^ { 2 }}}{2 \mathrm{gD}}+\frac{\mathrm{kv}^{2}}{2 \mathrm{~g}} \\
& 23028
\end{aligned}
$$


Table I is a tabulation of the methods used to evaluate individual pressure losses for each component fitting and piping for a primary loop.

\section{TABLE I}

\section{REACTOR COOLANT LOOP LOSSES}

(Based on Babcock'\& Wilcox

Boiler Loop)

\begin{tabular}{|c|c|c|c|c|c|}
\hline \multicolumn{2}{|c|}{$\begin{array}{l}\text { Component } \\
\text { Description }\end{array}$} & \multicolumn{2}{|c|}{ Quantity } & \multicolumn{2}{|c|}{$\begin{array}{l}\text { Pressure Drop } \\
\text { Determination }\end{array}$} \\
\hline Hump\#" & & 1 & & Square F & Function \\
\hline Boiler & & 1 & & 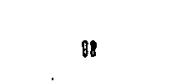 & 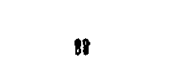 \\
\hline Flowmeter & & 1 & & $"$. & $s$ \\
\hline Gate Valve & & 4 & & $K=0.2$ & ? \\
\hline Check Valve* & & 1 & & $\bar{K}=2.0$ & \\
\hline 900 Ells & & 3 & & $K=0.15$ & \\
\hline $60^{\circ} \mathrm{EIIs}$ & & 1 & • & $K=0.12$ & \\
\hline $30^{\circ} \mathrm{E}$ Ells & & $i$ & & $\mathrm{~K}=0.07$ & \\
\hline $\left.15^{\circ} \mathrm{E}\right] 1 \mathrm{~s}$ & & 2 & & $K=0.05$ & \\
\hline $180^{\circ} \mathrm{E}$ ils & & 1 & & $K=0.20$ & \\
\hline$R \times$ Entrance & & 1 & & $K=0.68$ & \\
\hline Rx Exit & & 7 & & $K=0.36$ & \\
\hline $\mathrm{T}_{\mathrm{H}}$ Pipe & . & $\begin{array}{c}\text { Axial Feet } \\
41.6\end{array}$ & $\begin{array}{l}\text { Length } \\
\text { t }\end{array}$ & Fanning & Equation \\
\hline $\mathrm{T}_{\mathrm{C}}$ Pipe & & $\begin{array}{r}\text { Axial Leng } \\
58.3\end{array}$ & & 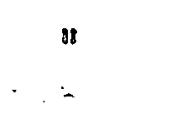 & . \\
\hline
\end{tabular}

$\operatorname{Rx} P . V 。$

Square Function

* Idle Pump Loss

* Estimate

The results of this calculation are shown on curve 425124 .

(The difference between the pressure drops of the Babcock \& Wilcox and the Foster Wheeler loops at low flows are negligible). 
The coolant system pressure drop can be represented by the following equations:

$$
\begin{aligned}
\mathrm{H} & =\mathrm{K}_{e} \mathrm{Q}^{\mathrm{n}} \\
\text { or } \Delta \mathrm{P} & =\mathrm{K} \mathrm{w}^{\mathrm{n}}
\end{aligned}
$$

$$
\begin{aligned}
\text { where } \mathrm{N} & =\text { slope of curve } \cong 2 \\
\mathrm{~K}_{\mathrm{C}} & =\text { curve intercept } \\
\mathrm{H} ;(\Delta \mathrm{P}) & =\text { Total system pressure loss, ft; (psi) } \\
Q_{;} W \quad & =\text { Loop flowrate, gpm; (lb/hr) }
\end{aligned}
$$

The equation of curve No. 425124 is $\Delta P=5.89 \times 10^{-12} W^{2}$

Equating this pressure drop equation to the thermal driving head:

the following results:

$$
\Delta P=5.89 \times 10^{-12} W^{2}=\frac{\Delta P}{I_{4}}
$$

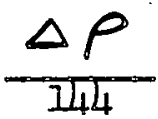

where $\mathrm{H}$ a effective elevational difference between the heat source and heat sink, f.t. $\Delta p=$ density differences between hot and cold legs of coolant loop.

The density difference may be expressed as a function of the temperature difference at a constant system pressure

$$
\begin{aligned}
\Delta \rho=\rho_{\mathrm{s}}-\rho_{\mathrm{h}} & =\Delta \mathrm{T} \text { at } \overrightarrow{\mathrm{T}}_{\mathrm{P}} \\
& =0.065 \mathrm{~T}
\end{aligned}
$$

so that

$$
5.89 \times 10^{-12} \mathrm{~W}^{2}=\frac{\mathrm{H} \times 6.5 \times 10^{-2} \cdot \Delta \mathrm{T}}{.144}
$$

However $\Delta \mathrm{T}$ can also be expressed as

$$
\Delta T=\frac{Q}{W C P}
$$

Substituting this relationship for $\Delta \mathrm{T}$ into the previous equation and solving for the coolant flowrate,

$$
W=425^{3} \sqrt{\frac{Q H}{C P}}
$$

$$
235030
$$


At rated heat sink capacity (1000 kw/10op) the predicted PWR natural convection coolant flowrate is $1.325 \times 10^{5} \mathrm{lb} / \mathrm{hr}$ per loop (compared to $1.55 \times 105 \mathrm{lb} / \mathrm{hr}$ by the approximate pressure drop method.

The average reactor coolant and steam temperatures can be accurately determined by utilizing heat balances for various time increments.

For a controlled emergency cooling system, such as designed for PWR, heat balances can be written for three situations; the time period prior to the operation of the system ${ }^{\prime} s$ heat sink, the time period in which the system's heat sink operates and the decay heat rate is greater than the heat dissipation rate; and, finally, the time period in which the heat sink operates and the decay heat rate is less than the heat dissipation rate. The following are the heat balances for each period:

1) System heat sink not operating

$$
Q_{0} q_{t \theta}-Q_{r} \theta=K_{1}\left(T_{S Q}-T_{s i}\right)+K_{2}\left(\tilde{T}_{\theta}-T_{T_{e}}^{\infty}\right)
$$

2) System heat sink operating

Decay heat rate greater than heat dissipation rate (Heat balance at end of emergency period)

$$
\begin{gathered}
\left.Q_{0} q_{t Q E}-Q_{r} \theta_{E}-Q_{S}(\Delta \theta)-Q_{0} q_{t \theta E}-Q_{0} q_{t p}\right) \\
=K_{I}\left(T_{S E}-T_{S_{i}}\right)+K_{2}\left(\vec{T}_{E}-\vec{T}_{i}\right)
\end{gathered}
$$

3) System heat sink operating

Decay heat rate less than heat dissipating rate. (Heat balance at end of emergency period)

(3)

$$
\begin{aligned}
Q_{0} q_{t Q E}-Q_{r} \theta_{E} & =\left(Q_{0} q_{t Q E}-Q_{0} q_{t}\right) \\
& =K_{1}\left(T_{S E}-T_{S i}\right)+K_{2}\left(\vec{T}_{E}-\vec{T}_{i}\right)
\end{aligned}
$$

The nomenclature for the above balances is as follows:

$Q_{0}=$ reactor output prior to scram (BTU/sec)

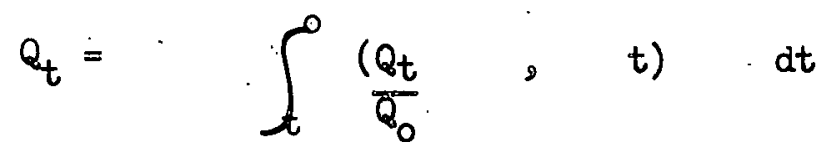

which can be evaluated for any time after scram by curve 398812 . $\theta=$ time after scram, seconds 


$$
\begin{aligned}
Q_{S} & =\text { rated heat sink capacity.: } \mathrm{BTU} / \mathrm{sec} . \\
Q_{0} & =\text { plant thermal radiation losses, } \mathrm{BTU} / \mathrm{sec} \\
\mathrm{K}_{1} & =\text { secondary system heat capacity; } \mathrm{BTU} / \mathrm{O}_{\mathrm{F}} \\
\mathrm{K}_{2} & =\text { primary system heat capacity; } \mathrm{BTU} /{ }^{\circ} \mathrm{F} \\
\mathrm{T}_{\mathrm{S}} & =\text { steam temperature, } \mathrm{O}_{\mathrm{F}} \\
\mathrm{T} & =\text { average reactor coolant temperature } \\
& \text { subscripts: } \\
\mathrm{OE} & =\text { final time after scram ( } 18000 \text { second } \mathrm{s}) \\
i & =\text { initial value } \\
\mathrm{P} & =\text { peak value }
\end{aligned}
$$

(occurs at time at which decay heat rate equals heat dissipation rate; for this study the time after scram is 720 seconds)

MTD $=\log$ mean temperature difference ${ }^{\circ} \mathrm{F}$

At the end of the emergency the heat transfer across the boiler is equivalent to the decay heat (This fact can be confirmed by calculating the induced coolant flowrate and balancing the MID against the predicted primary and secondary. temperatures at this point)。

Therefore, the average coolant temperature is known for any selected control steam temperatures at this time. Thus the right side of equations 2.) and 3) above are known: The only unknown quantity in equation (3) is qt, which correspinds to the time at which the steam control valve opens. Solving for $\mathrm{qt}_{\text {g }}$ if $\mathrm{qt}$ is equal or greater than 15.8 (the value at 720 seconds), the selected stem temperature peaks at this point; If qt is less than 15.8 , equation (2) must be used. In this equation the only unknown is $\Delta \theta_{9}$ the time spread about the 720 second peak value. Solving for $\Delta \theta$, the time at which the steam control valve opened for the selected steam temperature can be found. (assumed to be haif of the $\Delta \theta$ value). This procedure can be followed for a series of selected steam temperatures, which will yield a plot of steam temperature versus time after scram. The corresponding average coolant temperature occurring at these times and steam temperatures can be calculated by equation (I) (the only unknown being $T$ i). Primary volume surges and resulting pressure surges can be calculated by the difference in reactor coolant densities for the predicted average coolant temperatures. Since the secondary system contains saturated steam, the secondary side pressure is a function of the steam temperature. 
B. Secondary Circuit Pressure Drop

For the maximum steam flow ( $5250 \mathrm{lb} / \mathrm{hr}$ ), the pressure drop for the secondary circuit has been estimated to be approximately 8 psi.o The following was taken from a preliminary piping layout of the system used in this calculation:

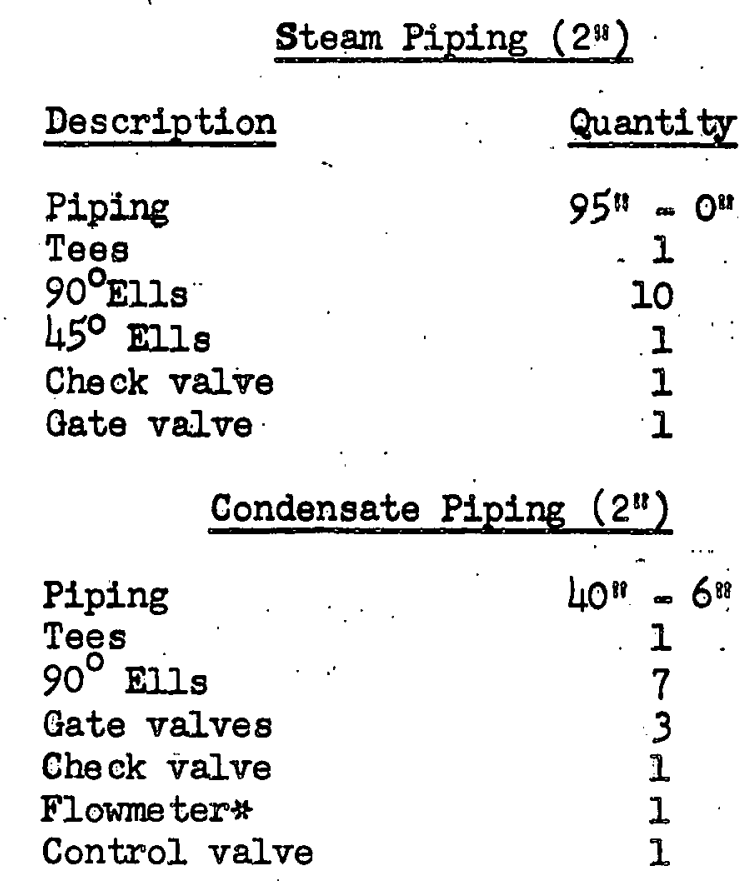

* The flowmeter ${ }^{\prime}$ s unecoverable pressure loss at full flow is estimated to be 10 inches of water. 


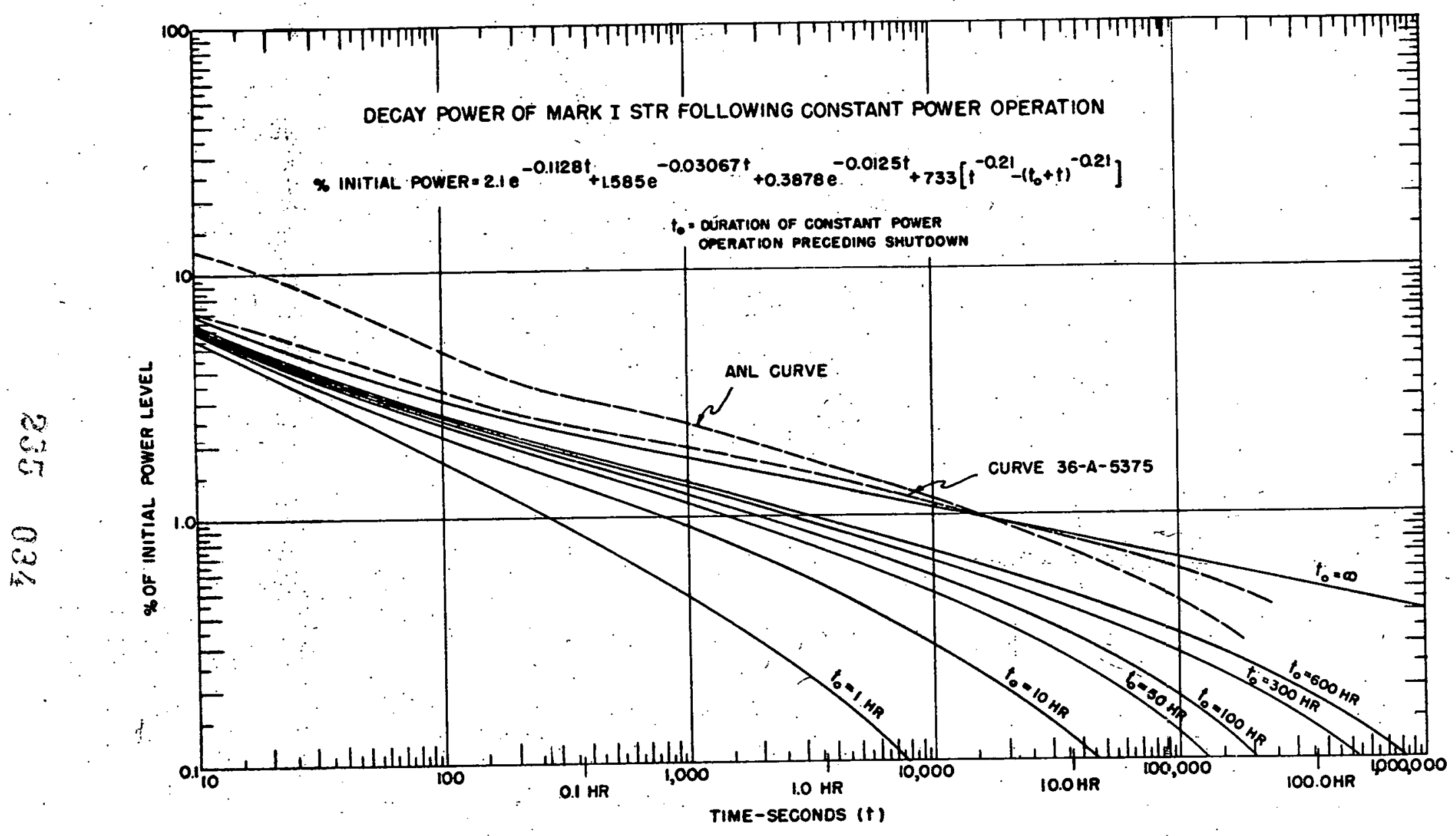

FIG. 8-3 


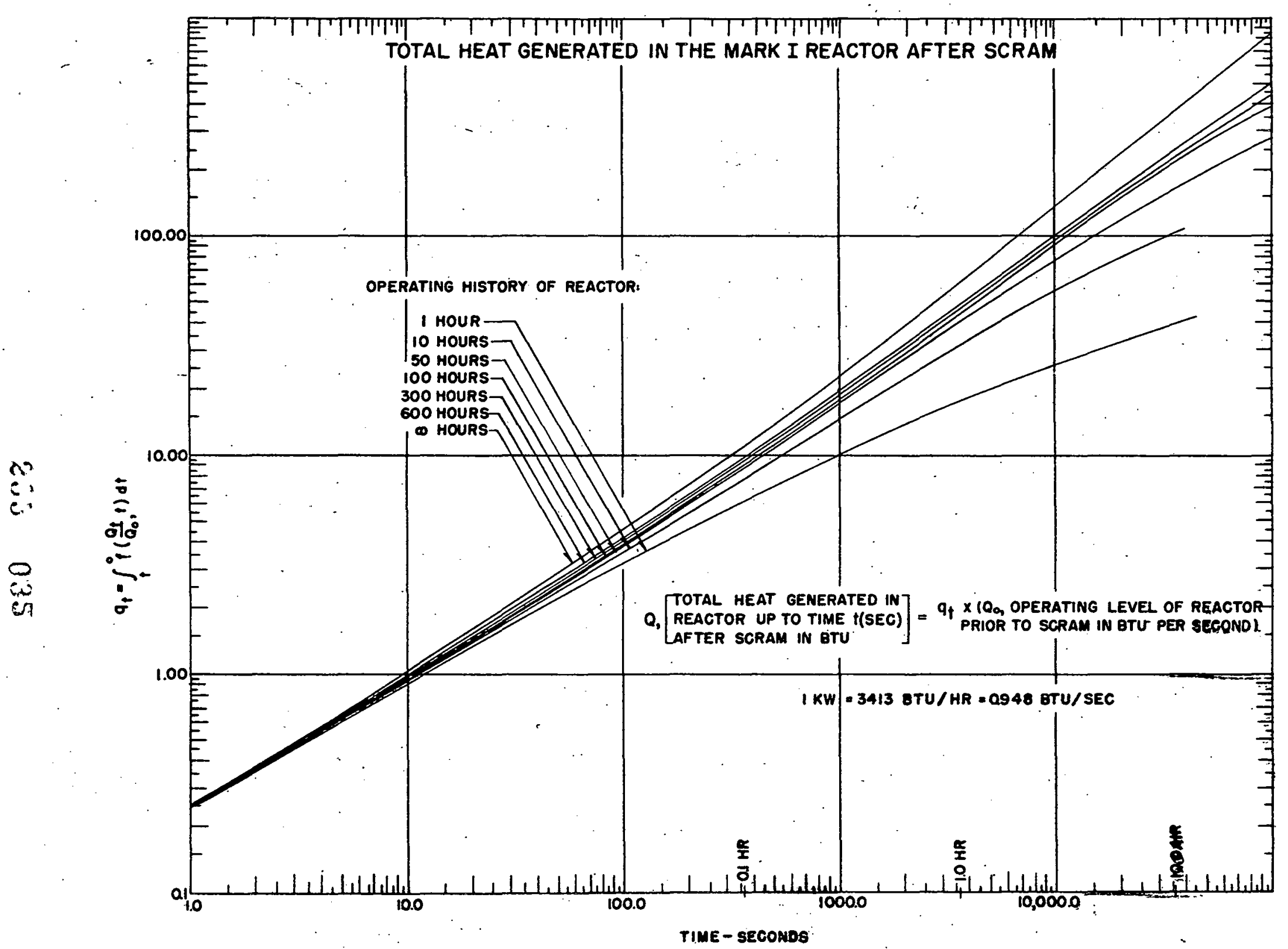

CUNRVE NO, 3988712 

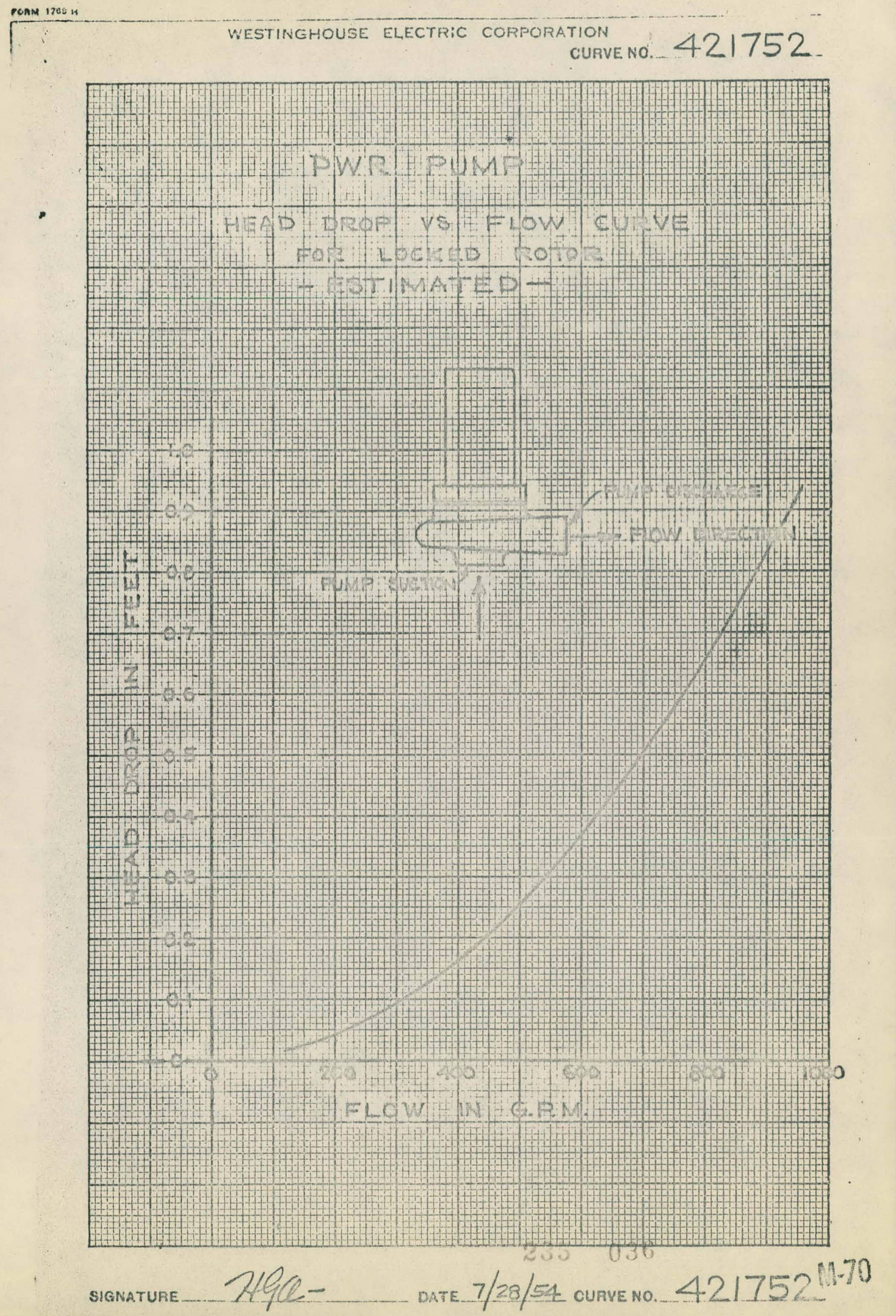
PWR - Predicted Average Plant Temperature Characteristics During

Emergency Cooling - Comparison of Various Heat Dissipation Rates -

Four Ioop Operation - Reference Core

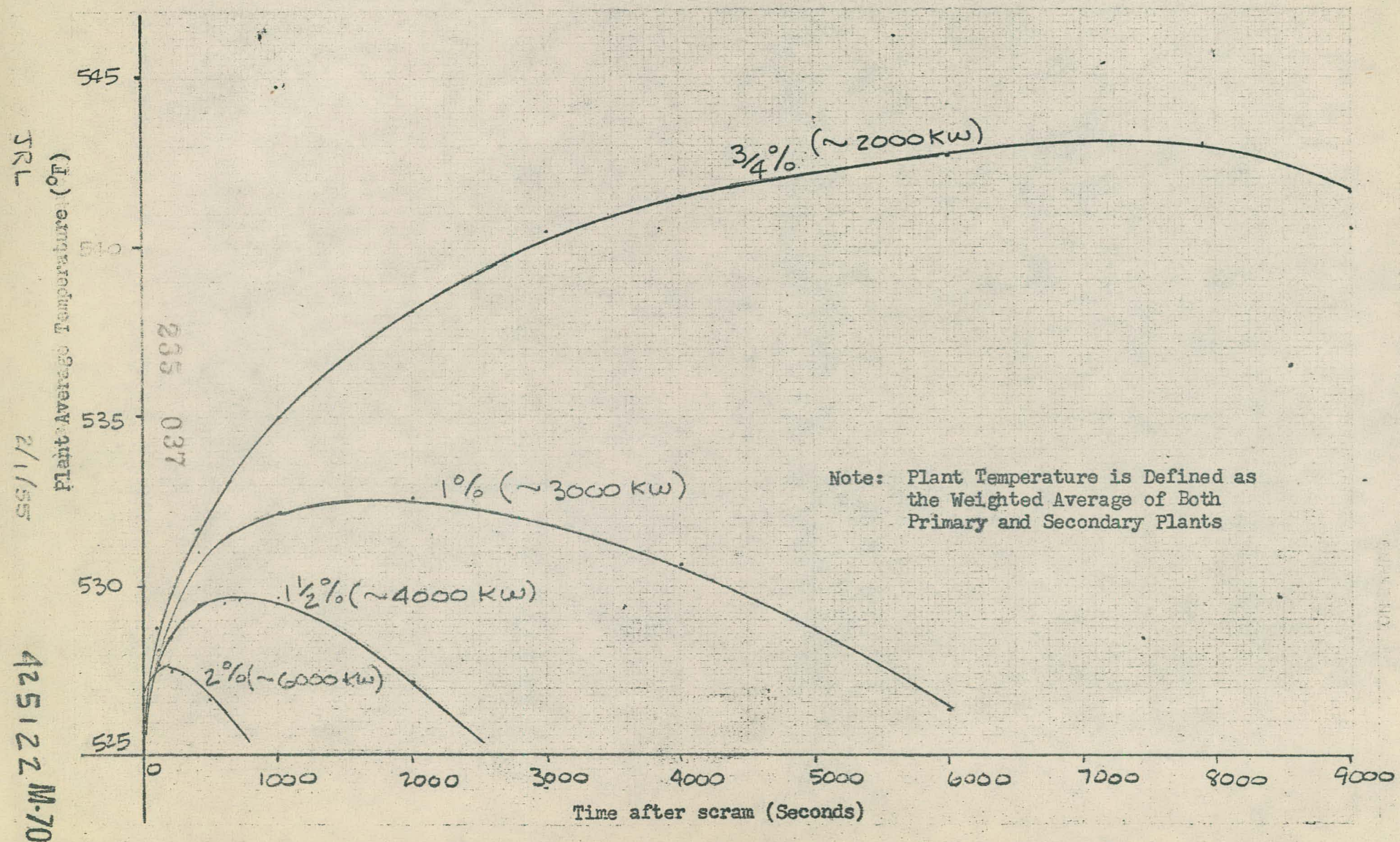


WR - Predicted Average Plant Temperature Characteristics During Emergency Cooling - Comparison of Various Cores - Constant Heat Dissipation Rate (4000 KW Total) - Four Loop Operation

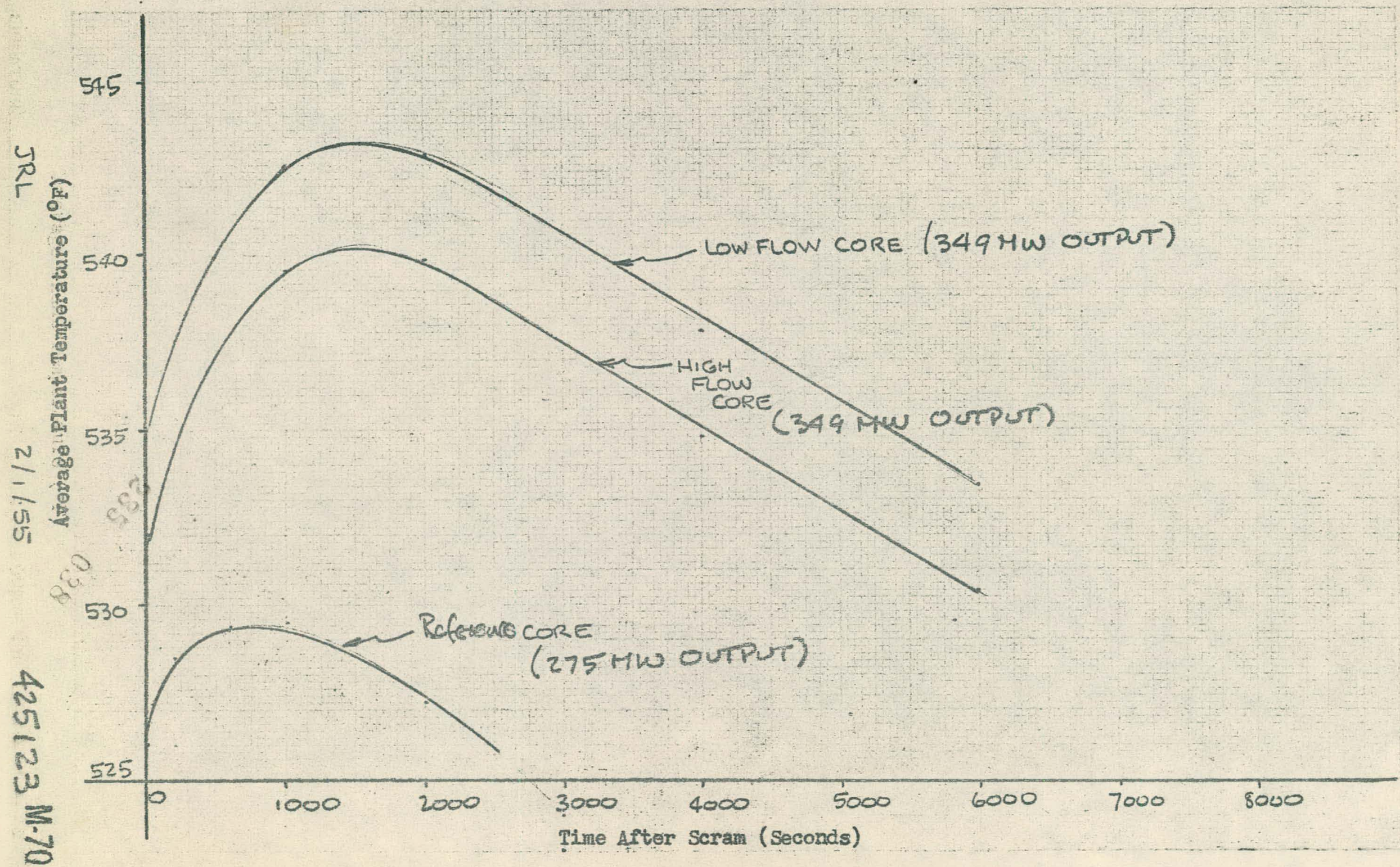




\section{PWR - Reactor Coolant System Pressure Drop Curve Including Reactor Vessel Losses During Emergency \\ Cooling - Four Loop Operation - Reference Core}

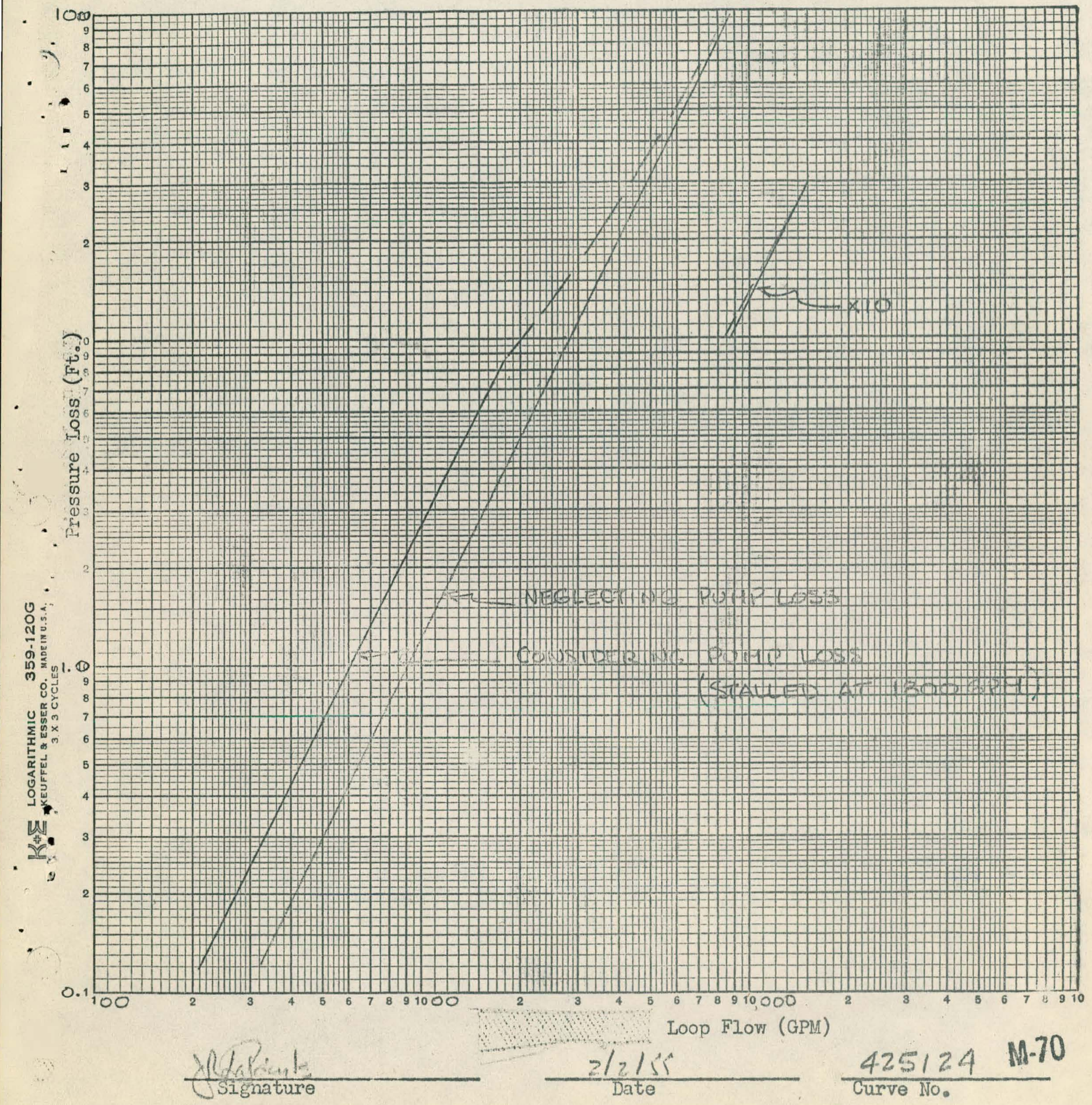


PNR - Predicted Plant Temperature Characteristics During an Emergency - Comparison of the Effect of Emergency Cooling vs No Cooling - Reference Core

Section II $1000-10000$ seconds

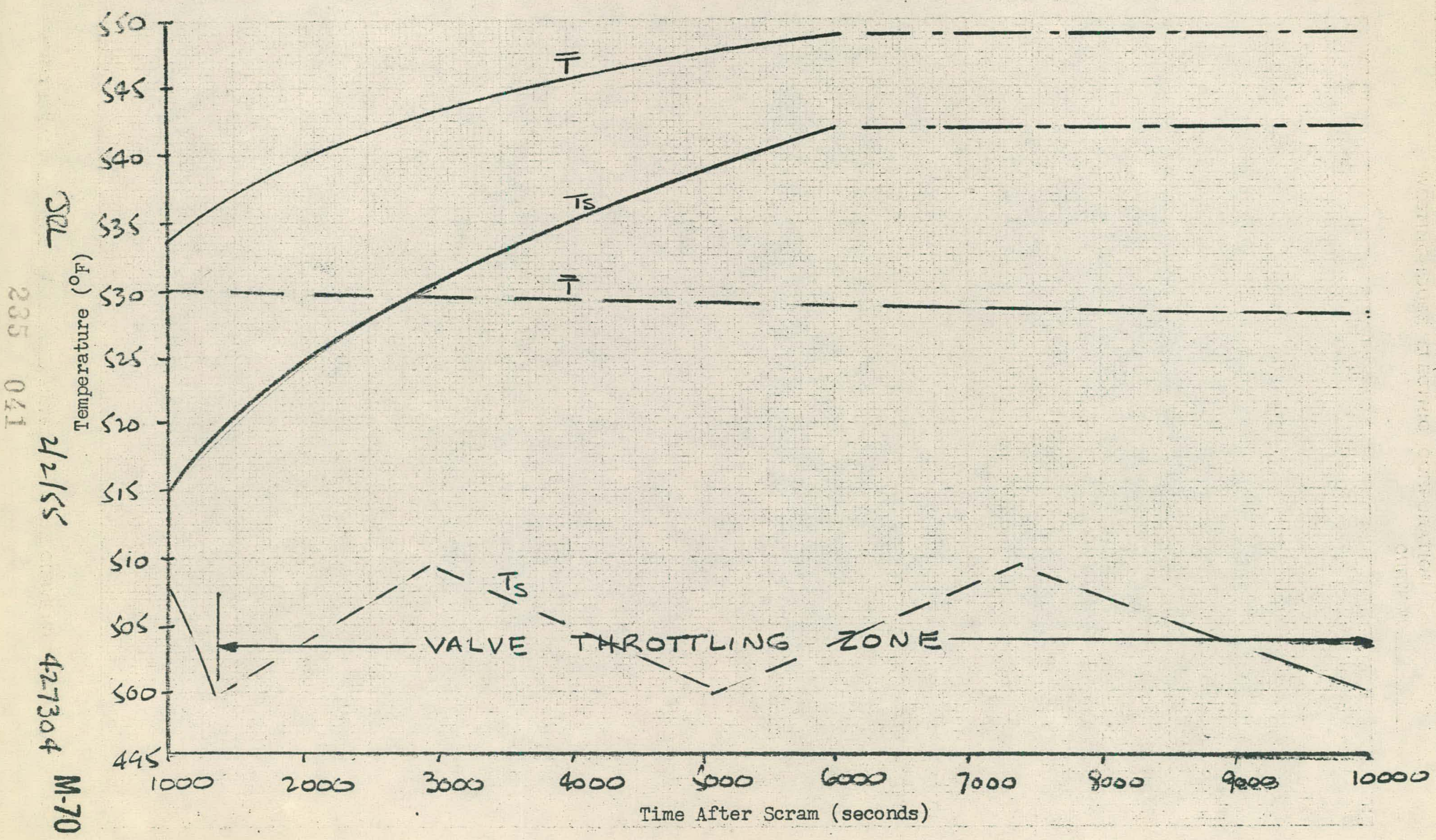




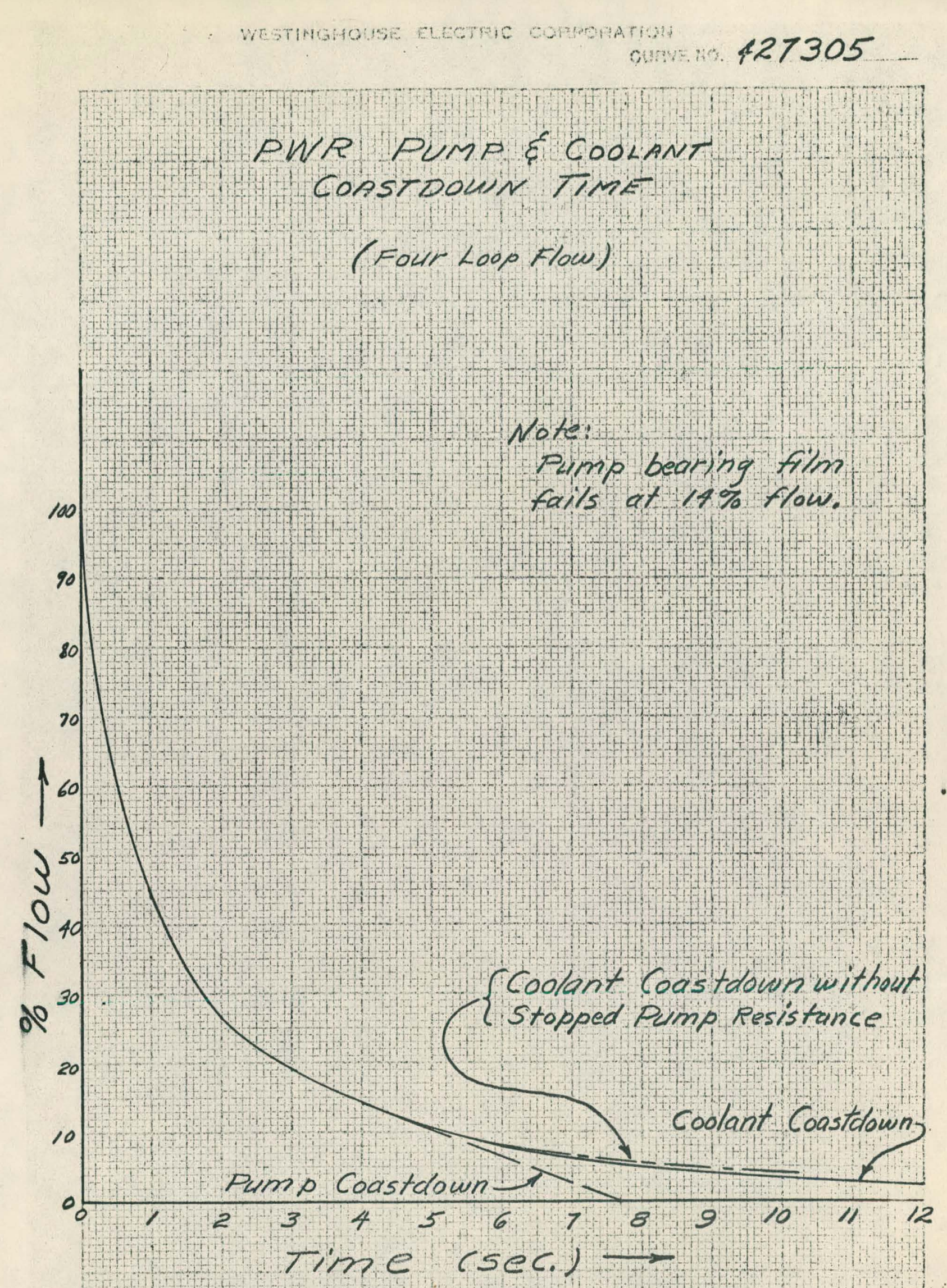


EMERGENCY COOLING-LOSS OF FLOW ACCDENT INITIAL POWER $275 \mathrm{MW}$

INITIAL FLOW $21 \times 10^{6} \mathrm{LB} / \mathrm{HR}$.

INITIAL EMERGENCY COOLING FLOW $0.63 \times 10^{6} \mathrm{LB} / \mathrm{HR}$

FLOW COASTDOWN TIME IS SEC $1 \times 10^{-4} \delta \mathrm{K} / O F$

ROD INSERTION DELAY I.S SEC

ROD INSERTION RATE $-1 \times 10^{-2} \delta \mathrm{K} / \mathrm{SEC}$

$P=2000 P 51 A$
$T_{G}=507 \circ \mathrm{F}$

60

HOT CHANNEL

EXIT QUALITY

50

$40 \%$

40

3
$\Sigma$
$\alpha$
$\frac{\alpha}{3} 30$
$\alpha$
$\alpha$
0
$\frac{\alpha}{4}$
$\mathbb{u}^{2}$

10

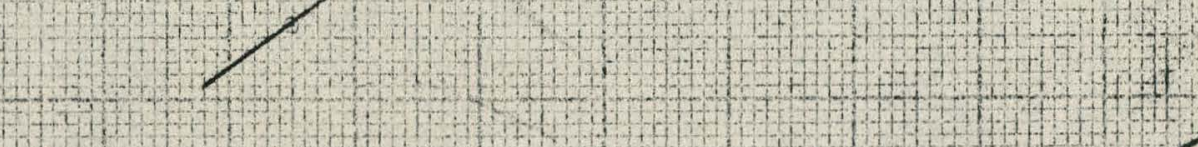
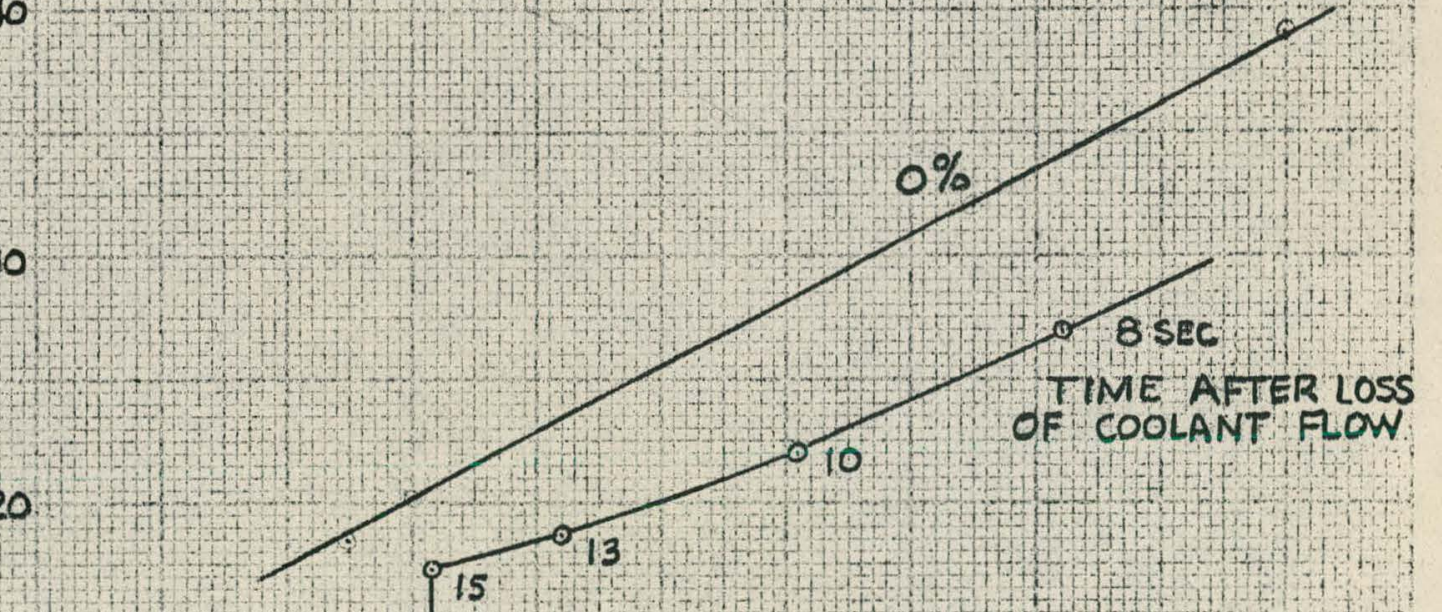

0

0

0.5

1.0

115

2.0

FLOW RATE, $10^{6} \mathrm{LB} / \mathrm{HR}$ 